\title{
EPISTEMOLOGIAS MARGINALIZADAS: A QUESTÃO RACIAL NO DEBATE SOCIOLÓGICO LATINO-AMERICANO
}

\author{
Franciane da Silva Santos Oliveira (D) \\ Universidade Estadual do Ceará
}

\section{Lia Pinheiro Barbosa (D)}

Universidade Estadual do Ceará

$\mathbf{N}$

este artigo abordaremos o lugar de inserção da questão racial e das epistemologias afrodiaspóricas no pensamento social e na produção sociológica latino-americana, partindo da premissa de que constituíram matrizes de construção de conhecimento silenciadas no contexto de surgimento do debate teórico-epistêmico e de consolidação da sociologia na América Latina. Ao situarmos a questão racial, o negro e as epistemologias da diáspora negra na construção e no fazer da ciência, em particular da sociologia, constatamos que são epistemologias marginalizadas historicamente, muito embora paulatinamente sejam incorporadas aos fundamentos sociológicos na transição do século XX ao XXI.

$\mathrm{O}$ processo de incorporação das matrizes epistêmicas do pensamento social negro conduziu ao enegrecimento da interpretação sociológica sob as lentes de intelectuais negras e negros, que passam a situar a questão racial como um problema social e sociológico decorrente da condição colonial e escravocrata que atravessou os diferentes países da América Latina, ao mesmo tempo em que desloca os elementos de análise desse processo histórico a partir da perspectiva negra. Deste modo, tecemos considerações em torno da marginalização das bases epistemológicas afrocentradas e afrodiaspóricas no âmbito do desenvolvimento 
da sociologia latino-americana e de seu método interpretativo, com o fito de descolonizar e enegrecer essa escrita sociológica, enaltecendo a vasta literatura produzida pela comunidade acadêmica negra e diaspórica ainda marginalizada e invisibilizada no âmbito das ciências sociais e, em especial, da sociologia em nosso continente.

O artigo está organizado em três seções: a primeira dedica-se ao contexto de consolidação da sociologia latino-americana e do debate racial. Posteriormente, adentramos na análise da inserção do negro na gênese do debate sociológico. Na terceira parte, abordaremos as e os intelectuais negros e o racismo científico, ao problematizar a autoridade epistêmica do intelectual branco e a invisibilização ou o lugar marginal conferido às epistemologias afrodiaspóricas na produção sociológica.

\section{Contexto da sociologia latino-americana e o debate racial}

O pensamento sociológico latino-americano se constituiu ao longo do século XX, muito inspirado nas influências múltiplas da Europa e da América do Norte, seguindo rigorosamente os cânones do método e da produção científica advindos dessas regiões. Por conseguinte, com a institucionalização das ciências sociais e de suas instituições de ensino e pesquisa, passa a ter legitimidade como pensamento científico, na medida em que o cientista social, por meio da objetividade do conhecimento, modifica e refina seu arsenal teórico e instrumental de investigação científica. ${ }^{1}$

Verificamos que na base dessas premissas teórico-metodológicas, a sociologia na América Latina se defronta com vários problemas intrínsecos ao processo de formação sociocultural, econômico e político que atravessa a conformação das sociedades e dos Estados nacionais na região. Desse contexto social emergem as questões que permearão o processo de elaboração e desenvolvimento do conhecimento científico

1 Octavio Ianni, Sociologia da sociologia latino-americana, Rio de Janeiro: Civilização Brasileira, 1971, p. 31. 
da sociologia latino-americana, com destaque para a história colonial da região, a conformação do Estado-nação e dos projetos nacionais nos diferentes países latino-americanos, a questão agrária, a industrialização e o desenvolvimento econômico, a mestiçagem e a indigenização.

$\mathrm{Na}$ medida em que o campo sociológico vai se consolidando e se espraiando, como resultado da dinâmica social existente, coaduna com o fazer científico em torno do imaginário social. E, pela via da pluralidade no campo das ideias, cria laços com outros campos do conhecimento, por exemplo, a economia política, a história, a ciência política e a antropologia. Isso pode ser compreendido pelo fato de estes temas "estarem fundamentalmente relacionados às transformações estruturais globais, [que] impõem aos cientistas sociais o alargamento das contribuições de cada disciplina”. ${ }^{2}$ Trata-se de nuances e tendências epistemológicas que exprimem a manifestação social de produções notáveis no âmbito da teoria do conhecimento. Destarte, de um lado,

a sociologia é vista como disciplina científica que pode proporcionar conhecimentos úteis à ação prática. De outro, o conhecimento sociológico surge como uma dimensão da realidade. Não apenas como dimensão justaposta, mas como elemento que participa da própria realidade. Num caso, ela é exterior e independente do objeto. No outro, aglutina sujeito e objeto, conhecimento e existência. Em ambos os casos, no entanto, ela aparece na constituição dos fenômenos, da própria realidade. Neste ponto é que a ciência e a consciência social se unem. ${ }^{3}$

O pensamento social latino-americano mais autônomo e original começa a se desenvolver em meados do século XIX. Naquela época aconteceram as independências das colônias em relação às metrópoles ibéricas e os novos Estados empenhavam-se na formação das nações, em desenvolver um pensamento próprio que refletisse ideias e costumes

2 Ianni, Sociologia da sociologia, p. 31.

3 Ianni, Sociologia da sociologia, p. 35. 
da nação e falasse do "povo para o povo”, em criar uma comunidade imaginada que compreendesse todas as classes que compunham as jovens repúblicas e, no caso do Brasil, "um império tropical”. ${ }^{4}$ Sob a égide da dominação colonial, a região não tinha condições de produzir suas próprias ideias, importando-as da metrópole e de outros centros europeus, ou seja, consolidando uma via única de absorção das teorias advindas do chamado "Velho Mundo”. Como destacado por Marini, nas sociedades dependentes da América Latina,

ser culto significava estar em dia com as novidades intelectuais que se produziam na Europa. A estatura de nossos pensadores se media por sua erudição em relação às correntes europeias de pensamento e à elegância com que aplicavam as ideias importadas para nossa realidade. ${ }^{5}$

Dessa forma, o pensamento latino-americano se dava de maneira imitativa, como um pensamento reflexo, ${ }^{6}$ derivado das condições materiais reproduzidas em nossas sociedades. Essa postura, também intrínsecaà fundação das bases de uma sociologia latino-americana, se assemelha muito mais a um servilismo intelectual, ${ }^{7}$ ou ainda ao que Rosenmann denominou como uma paralisia ou um complexo de inferioridade, uma sorte de colonialismo cultural, ou mesmo de dependência cultural na forma como a sociologia clássica foi recepcionada eassimilada emnossa região. ${ }^{8}$ Nessa recepção, houveum extravio de origem no desenvolvimento de uma teoria social latino-americana, ao traçar um modelo teórico-metodológico e categorial que conduzia a um enquadramento do olhar sociológico na observação e análise de fatos sócio-históricos,

4 Benedict Anderson, Comunidades imaginadas: reflexões sobre a origem e difusão do nacionalismo, São Paulo: Companhia das Letras, 2008, p. 282.

5 Ruy Mauro Marini, Dialética da dependência, Petrópolis: Vozes, 2000, pp. 259-260.

6 Guerreiro Ramos, A redução sociológica, Rio de Janeiro: Iseb, 1958, p. 21.

7 Orlando Fals Borda, Una sociología sentipensante para América Latina, Buenos Aires: CLACSO, 2015, p. 224.

8 Marcos Roitman Rosenmann, Pensar América Latina. El desarrollo de la sociología latinoamericana, Buenos Aires: CLACSO, 2008, p. 22. 
cujos princípios se encontravam imersos no universo cultural do ocidente europeu e em uma racionalidade política atrelada a uma ordem social instituída a partir dos valores da sociedade industrial. A nascente sociologia latino-americana ignorou o que éramos antes dos processos de colonização, sobretudo em relação a quais ontologias e epistemologias conformavam o ordenamento social, cultural e político das diferentes sociedades que habitavam o Abya Yala, nosso território anterior à conquista.

É válido destacar que a gênese da sociologia latino-americana possui um duplo viés: por um lado, aceita a maternidade e paternidade europeia em seus fundamentos teórico-metodológicos, não só porque a Europa (mais precisamente França e Alemanha) é reconhecida como o berço da sociologia no século XIX, mas sobretudo pelo contínuo fluxo da América Latina à Europa no processo de formação dos pensadores que alavancaram as ciências sociais em nossa região, em grande parte formados em universidades europeias. Soma-se a este fator a tardia fundação das primeiras faculdades de sociologia na região, criadas somente em meados do século XX.

De outro lado, há aqueles que, mesmo formados em universidades europeias e estadunidenses, retornaram à região instigados a conformar uma sociologia de caráter latino-americano e latino-americanista, a partir de um marco teórico, de um método e de categorias que dessem conta da análise histórica e sociológica de nossas especificidades, idiossincrasias e dinâmicas socioculturais e da ordem da dialética político-econômica em relação aos demais continentes. Exemplar desse esforço de construção de uma sociologia original para a América Latina é constatada na produção intelectual de meados do século XX, notadamente em Casanova, Stavenhagen, Bambirra, Fals Borda, Dussel, para citar alguns. ${ }^{9}$ Logo, os intelectuais latino-americanos trataram de estabelecer uma tradição original e independente na teorização sobre

9 Pablo Gonzalez Casanova, Sociología de la explotación, México: Siglo XXI, 1969; Rodolfo Stavenhagen, Sociología y Subdesarrollo, México: Siglo XXI, 1971; Vania Bambirra, El capitalismo dependiente latinoamericano, México: Siglo XXI, 1974; Fals Borda, Una sociologia sentipensante; Enrique Dussel, "Europa, modernidad y eurocentrismo” in Edgardo Lander (comp.), La colonialidad del saber: eurocentrismo 
a região, institucionalizando as ciências sociais, em particular a sociologia e a economia, imbuídos pelo desejo de atribuir-lhes um caráter comprometido na conformação de um pensamento autônomo sobre a problemática latino-americana.

O esforço de consolidação de uma abordagem sociológica genuína acompanhou o processo de fundação de instituições de pesquisa e ensino, tais como a Comissão Econômica para a América Latina e o Caribe (Cepal), em 1948, e a criação da Faculdade Latino-Americana de Ciências Sociais (FLACSO), em 1957, instâncias que contribuíram com a delimitação de chaves interpretativas para a abordagem da natureza do desenvolvimento social e político-econômico, em perspectiva latino-americana e caribenha. Em 1959 foi criada a primeira Faculdade de Sociologia, na Universidad Nacional de Colombia, por Orlando Fals Borda e Camilo Torres, o primeiro impulsor da chamada Sociologia Sentipensante, em alusão ao princípio do pensar nuestro americano, de ruptura com a adoção cega de modelos teóricos que têm seus referentes na Europa e Estados Unidos e que promovesse, em conjunto com as epistemologias dos povos da América Latina e do Caribe, teorias e conceitos para um processo político libertador, de vínculo entre teoria e prática em um dinamismo criador de uma sociologia da libertação. ${ }^{10}$

Portanto, na metade do século XX inaugura-se o desenvolvimento de uma teoria e de um método próprios no campo da sociologia, isto é, de um pensar sociológico latino-americano genuíno e inerente à região, sem perder seu caráter dialético com a geopolítica da produção do conhecimento. Nessa direção, outros centros de referência para o pensamento social latino-americano foram criados, como o Centro Latino-Americano de Pesquisas em Ciências Sociais (CLAPCS), criado ainda na década de 1950 no Rio de Janeiro, o Centro de Estudios Latinoamericanos (Cela), fundado em 1960 pela Facultad de Ciencias Políticas y Sociales da

y ciencia sociales. Perspectivas latinoamericanas (Colección Sur-Sur, Buenos Aires: Clacso, 2005), pp. 25-34.

10 Fals Borda, Una sociologia sentipensante, p. 224. 
Universidad Nacional Autónoma de México, e o Conselho Latinoamericano de Ciências Sociais (CLACSO), em 1967. Ianni destaca que a FLACSO e o CLAPCS foram instituições instaladas sob os auspícios da Unesco, sob a supervisão de seu Conselho de Diretores. ${ }^{11}$ Destarte, Ianni aponta que "as periodizações na história da sociologia latino-americana e a distinção entre fases pré-científica, de institucionalização e propriamente científica é um artifício descritivo que às vezes esquematiza e reduz o significado do pensamento criador na ciência”. ${ }^{12}$

Nesse mesmo período observa-se uma aproximação com a África, de caráter diplomático na abertura de relações internacionais, bem como no interesse teórico-político acerca do debate anticolonialista e das lutas independentistas que aconteciam em diferentes países desse continente. É desse período a criação, no Brasil, de institutos e centros de pesquisa dirigidos aos estudos africanos: em 1959, do Centro de Estudos Afro-Orientais, da Universidade Federal da Bahia; a fundação, em 1961, do Instituto Brasileiro de Estudos Afro-Asiáticos, que estava vinculado à Presidência da República, sendo fechado em 1964; o Centro de Estudos e Cultura Africana, em 1963, vinculado à Faculdade de Filosofia da Universidade de São Paulo (USP), hoje denominado Centro de Estudos Africanos (CEA) e, em 1973, o Centro de Estudos Afro-Asiáticos (CEAA), no Rio de Janeiro.

Essas etapas de consolidação de centros e institutos de pesquisas com franca incorporação de outras matrizes epistêmicas de conhecimento envolvem o pensamento científico e as configurações sociais da vida no que tange às relações exprimidas e modificadas nas vinculações das nações da América Latina, juntamente com países de outros continentes. Entretanto, nessa empreitada, ainda se refletem na sociologia "as peculiaridades da dependência estrutural e histórica que caracteriza as sociedades da América Latina”. ${ }^{13}$ Essa cultura científica dependente nos leva a crer que a produção do conhecimento no campo sociológico "continua a

11 Ianni, Sociologia da sociologia, p. 16.

12 Ianni, Sociologia da sociologia, p. 17.

13 Ianni, Sociologia da sociologia, p. 39. 
revelar influências acentuadas da produção intelectual norte-americana, francesa, alemã, inglesa”. ${ }^{14}$ Sobre essa relação, Ianni aponta que são as

relações econômicas, políticas e culturais que caracterizam, mantêm e desenvolvem as desigualdades e desequilíbrios internos nos países dependentes. Entretanto, quando se coloca a problemática do "subdesenvolvimento" em termos de colonialismo interno, dependência estrutural e imperialismo modificam-se essencialmente a colocação teórica e as implicações práticas da questão. A partir deste ponto, a problemática sociológica do "subdesenvolvimento" implica no abandono da perspectiva sincrônica e funcionalista, em que se fundamenta a análise dualística e o princípio da causação circular. ${ }^{15}$

Essa dialética inerente à consolidação das ciências sociais e, em particular da sociologia latino-americana, incide no método adotado e evidencia as contradições da não superação do colonialismo interno ${ }^{16} \mathrm{e}$ o predomínio de um olhar sociológico atrelado ao paradigma ocidental moderno europeu, ${ }^{17}$ em sua dependência científica e subordinação epistêmica no uso de categorias analíticas advindas da Europa e influenciadas por suas epistemologias para a interpretação da realidade social latino-americana. Essa prática do fazer ciência unicamente sob os cânones da ciência eurocentrada, reconhecendo nela a ciência universal, não se atém ao passado, mas permanece em vigor na contemporaneidade, muito embora tensionada e em disputa pela abertura de um diálogo horizontal entre a diversidade de paradigmas civilizatórios.

Dussel, por sua vez, desconstrói e desmistifica o conceito de modernidade europeia enquanto expressão do espírito europeu. ${ }^{18} \mathrm{O}$ autor

\footnotetext{
14 Ianni, Sociologia da sociologia, p. 41.

15 Ianni, Sociologia da sociologia, pp. 55-56 (grifos no original).

16 Casanova, Sociología de la explotación, p. 224.

17 Dussel, “Europa, modernidad y eurocentrismo”, p. 48.

18 Dussel, “Europa, modernidad y eurocentrismo”, p. 184.
} 
critica a centralidade da Europa na história mundial e, sobretudo, a imposição do mito de que sua produção teórica deve ser assimilada como uma ciência universal, fator determinante da modernidade, e desvela esse mito inventado pelo europeu que assentou as raízes de sua racionalidade pela via do ocultamento de outros paradigmas epistêmicos oriundos de outras regiões. A propósito da categoria “eurocêntrico”, assevera que é um conceito da modernidade que assenta a Europa como lugar da racionalidade, às custas do silenciamento de saberes produzido nas Américas, na África e na Ásia. ${ }^{19}$ Em nossos termos, se trata de um soterramento epistêmico, ancorado em sete pontos fundamentais que caracterizam o que Dussel denomina como "mito da modernidade”, quais sejam:

1. La civilización moderna se autocomprende como más desarrollada, superior (lo que significará sostener sin conciencia una posición ideológicamente eurocéntrica).

2. La superioridad obliga a desarrollar a los más primitivos, rudos, bárbaros, como exigencia moral.

3. El camino de dicho proceso educativo de desarrollo debe ser el seguido por Europa (es, de hecho, un desarrollo unilineal y a la europea, lo que determina, nuevamente sin conciencia alguna, la "falacia desarrollista"). 4. Como el bárbaro se opone al proceso civilizador, la praxis moderna debe ejercer en último caso la violencia si fuera necesario, para destruir los obstáculos de la tal modernización (la guerra justa colonial).

5. Esta dominación produce víctimas (de muy variadas maneras), violencia que es interpretada como un acto inevitable, y con el sentido cuasi-ritual de sacrificio; el héroe civilizador inviste a sus mismas víctimas del carácter de ser holocaustos de un sacrificio salvador (el indio colonizado, el esclavo africano, la mujer, la destrucción ecológica de la tierra, etcétera).

19 Dussel, "Europa, modernidad y eurocentrismo”, p. 185. Cristina Borges, “A crítica descolonial em Enrique Dussel: desmitificação da modernidade europeia”, Poiesis: Revista de Filosofia, v. 15, n. 2 (2017), pp. 184-195. 
6. Para el moderno, el bárbaro tiene una “culpa” (el oponerse al proceso civilizador) que permite a la "Modernidad" presentarse no sólo como inocente sino como "emancipadora” de esa "culpa” de sus propias víctimas. 7. Por último, y por el carácter “civilizatorio” de la "Modernidad”, se interpretan como inevitables los sufrimientos o sacrificios (los costos) de la “modernización” de los otros pueblos “atrasados” (inmaduros), de las otras razas esclavizables, del otro sexo por débil, etcétera. ${ }^{20}$

Isso demonstra que, de acordo com a perspectiva de Dussel, épreciso superar e desconstruir a modernidade para que se supere a imposição do sistema-mundo, na divisão entre centro e margem, ao mesmo tempo em que se propõe um novo paradigma de pensamento, que associe alteridade em seu conjunto. Dessa forma, munidas pela reflexão dusseliana, na esteira da construção e reivindicação pelo pensamento descolonizado, argumentamos em favor da relevância de desconstruir os modelos paradigmáticos que compõem os espaços acadêmicos e o campo cognitivo e epistêmico, escavando saberes subjugados e epistemologias marginalizadas.

Partimos de uma vindicação, ${ }^{21}$ qual seja, a de que uma sociologia erigida na América Latina e que não reconheça ou que ignore, na construção de seu método e marco conceitual, a questão racial e o lugar do negro como elementos fundantes, portanto indissociáveis daquilo que somos como sociedades, torna-se uma sociologia estéril, incompleta e com limitações naquilo que se propõe a analisar. Em outros termos, se a sociologia clássica nasce propondo-se examinar os fenômenos sociais intrínsecos às sociedades industriais e à própria gênese do capitalismo na Europa, quais seriam os fenômenos sociais de grande envergadura histórica que deveriam ocupar os processos analíticos da sociologia construída na América Latina e por uma geração de intelectuais latino-americanos?

20 Dussel, “Europa, modernidad y eurocentrismo”, p. 49.

21 Inspirada em Mariátegui, ao reivindicar o "problema do índio” como imprescindível à teoria crítica. José Carlos Mariátegui, Sete ensaios de interpretação da realidade peruana, São Paulo: Expressão Popular, 2008. 
A história colonial e a escravidão são os fatos sociais que estruturaram, ao longo de mais de cinco séculos, a base do capitalismo e o ordenamento sociocultural, a natureza dos Estados nacionais e das relações de dominação e de produção na América Latina. Portanto, a questão racial e o lugar atribuído ao negro que emergem desse processo histórico deveriam ser reconhecidos enquanto fenômeno em si a ser pensado, analisado e teorizado sociologicamente. Não há como estruturar uma sociologia latino-americana desconsiderando essa condição de origem na formação sócio-histórica de nossas sociedades. Outrossim, a própria presença afrodiaspórica em nosso continente deveria interpelar esse fazer sociológico, no sentido de identificar as matrizes onto-epistêmicas advindas da África e que se imiscuíram em nossa formação sociocultural.

Uma geração de intelectuais dos umbrais do século XX foram fundamentais para alavancar o estudo amiúde em torno das epistemologias e ancestralidades africanas e seu legado epistêmico e ontológico na introjeção de valores espirituais e religiosos, na musicalidade, em sociabilidades forjadas em condição de resistência política à violência colonial, nas expressões linguísticas que revelam um universo vocabular que porta, em seu âmago, uma filosofia própria e em uma estética do universo afro. Essa herança africana torna-se o centro desse pioneiro reconhecimento da África e de seus aportes epistêmicos no âmbito dos debates antropológicos, etnológicos, historiográficos e literários na América Latina e no Caribe.

Insere-se nessa construção de conhecimento afrodiáspórico a produção intelectual caribenha do cubano Fernando Ortiz, precursor dos estudos sobre a cultura negra em Cuba, notadamente inaugurados pela trilogia de estudos afroculturais Negros brujos (1907), Los negros esclavos (1916) e Los negros curros, publicado como edição póstuma em 1986. Intelectual sumamente envolvido com a vida política e cultural de Cuba, fundou as revistas El eco de la Cátedra, Revista Bimestre Cubana, Archivos del Folklore Cubano e Estudios Afrocubanos e escreveu os livros La Africanía de la Música Folklórica de Cuba (1950) e Los Instrumentos de la Musica Afrocubana (1952-1955). É válido salientar a expressiva 
participação de Fernando Ortiz na $3^{\text {a }}$ Conferência Pan-Americana, no Congresso Internacional de Americanistas e na $6^{a}$ Conferência Internacional Pan-Americana, eventos realizados em Washington, Roma e Havana, respectivamente. Em 1940, publica Contrapunteo cubano del tabaco y del azúcar, obra em que introduz o conceito antropológico de transculturação, central em sua análise sobre a formação da identidade cubana a partir do encontro com a cultura africana. ${ }^{22}$

Lygia Cabrera é outro referente imprescindível nos estudos da arte e da religião africanas e sua influência na arte cubana. Com enfoque na etnologia e na antropologia, iniciou na década de 1920 seus estudos sobre a presença da cultura africana nas fontes linguísticas, antropológicas e das religiões e culturas afro-cubanas. A pensadora se dedicou à produção de coletâneas históricas, resultado de trabalho etnográfico, com destaque para a produção de dicionários e glossários de idiomas e tradições afro-cubanas. A obra El Monte. Notas sobre las religiones, la magia, las supersticiones y el folklor de los negros criollos y del pueblo de Cuba (1954) é considerada um clássico dos saberes folclóricos e afro-cubanos arraigados no povo cubano desde os tempos da escravidão colonial. A obra aborda a base epistemológica da origem do universo africano e de seus deuses, da personificação dos animais, da diversidade botânica e das ontologias dos modos de viver em África. ${ }^{23}$ Outra obra central de Cabrera é Anago: vocabulario Lucumi (1970), um estudo da linguagem lucumi e suas adaptações ao espanhol.

Na década de 1940, o antropólogo mexicano Gonzalo Aguirre Beltrán pesquisou os antecedentes da população negra no México e a presença das tradições afro-mexicanas entre as culturas indígenas. Em um país marcado pelo predomínio dos estudos indigenistas, Aguirre Beltrán foi uma voz fundamental no argumento em torno da negligência historiográfica

22 Fernando Ortiz, El contrapunteo cubano del tabaco y del azúcar, La Habana: Editorial de Ciencias Sociales, 1940.

23 Lygia Cabrera, El Monte. Notas sobre las religiones, la magia, las supersticiones y el folklor de los negros criollos y del pueblo de Cuba, La Habana: Ediciones C.R., 1954. 
e antropológica acerca da história da população negra no México, por certo uma discussão que perdura até nossos dias. Entre suas obras, destacam-se La población negra de México, 1519-1810 (1946), El proceso de aculturación (1957) e Cuijla, esbozo etnográfico de un pueblo negro (1958).

Outro intelectual imprescindível é o historiador Eric Williams, de Trinidade e Tobago, cuja obra Capitalismo \& Escravidão (1944), é seminal para a historiografia da escravidão e suas interfaces com a consolidação do capitalismo industrial alcançado pela Inglaterra. O pensador analisa três elementos que estão relacionados à abolição do tráfico transatlântico de escravos, quais sejam: o entendimento da escravidão negra como um fenômeno econômico, incrustado em um racismo funcional à exploração de classe; a centralidade do complexo escravista transatlântico para a formação do capitalismo industrial na Inglaterra e o papel da resistência escrava para o declínio da escravidão. ${ }^{24}$ Fruto de uma visita à região caribenha, que lhe permitiu um profícuo diálogo com intelectuais da região, entre eles Fernando Ortiz, a obra The negro in the Caribbean (1942), é outro referente importante na análise da herança da economia açucareira escravista colonial para os povos negros das Antilhas. O principal legado intelectual de Williams reside em seu caráter contestatório da interpretação humanitarista da abolição predominante nos circuitos intelectuais da época. Na década de 1950, Eric Williams se vincula ao movimento de emancipação política de Trinidade e Tobago e sua obra, renegada a severas críticas de intelectuais por seu caráter contestatório quando de sua publicação, encontra receptividade a partir da década de 1960, sobretudo no cerne do debate anticolonial e das lutas independentistas na África.

A literatura afro-latino-americana também nos propiciou o contato com a cultura africana e com as bases epistêmicas dos costumes e tradições iorubás e bantu nas sociedades latino-americanas e caribenhas. Nesse campo, destaca-se o antropólogo colombiano Manuel Zapata Olivella e sua dedicação à história da cultura dos habitantes do Caribe colombiano,

24 Rafael de Bivar Marquese. "Capitalismo \& Escravidão e a historiografia sobra a escravidão nas Américas”, Estudos Avançados, v. 26, n. 75 (2012), pp. 341-354. 
sobretudo à vivência dos negros e dos indígenas. O romance Changó, el Gran Putas (1983) tornou-se sua obra clássica, uma narrativa epopeica da diáspora africana, desde as origens mitológicas de seus ancestrais, a escravidão e as relações coloniais nas Américas até os processos de resistência política, nas lutas de independência do Haiti, e contra a segregação e pelos direitos civis nos Estados Unidos.

$\mathrm{Na}$ contemporaneidade, destacam-se as análises realizadas pela filósofa jamaicana Sylvia Winter em torno das continuidades da modernidade colonial e do homem moderno a partir de uma teoria racial crítica. No ensaio intitulado "Rumo ao princípio sociogênico: Fanon, o enigma da experiência consciente, da‘identidade' e do que é ser 'negro'” (tradução nossa), Winter desenvolve um quadro teórico, por ela denominado "princípio sociogênico”, para analisar a experiência de construção da identidade do ser humano em uma perspectiva histórico-social, em que são incorporados referentes simbólicos resultantes de contextos culturalmente específicos. ${ }^{25}$ Inspirada pelo legado de Frantz Fanon, Winter argumenta que a sociogenia constitui uma teoria fundamental na superação de uma abordagem cartesiana da realidade social e, em um contexto histórico marcado pelo racismo, nos permite situar a categoria raça nas dinâmicas das relações sociais no continuum da colonialidade e da modernidade. Em "Desestabilizando a Colonialidade do Ser/Poder/Verdade/Liberdade: rumo ao humano, pós-homem, sua sobre-representação - um argumento" (tradução nossa), Winter nos explica como o Ocidente se apropriou da categoria raça para sobrepor uma interpretação de quem são os povos do sul global sob a ótica ocidental e, em particular, da posição epítome do homem europeu que se impôs como o epicentro epistêmico. ${ }^{26}$

25 Sylvia Winter, “Towards the Sociogenic Principle: Fanon, The Puzzle of Conscious Experience, of 'Identity' and What its Like to be 'Black'” in Antonio Gomez-Moriana e Mercedes Duran-Coga (orgs.), National Identities and Socio-Political Changes in Latin America (New York: Routledge, 2001), pp. 30-67 ש.

26 Sylvia Winter, "Unsettling the Coloniality of Being/Power/Truth/Freedom: Towards the Human, After Man, Its Overrepresentation - An Argument”, The New Centennial Review, v. 3, n. 3 (2003), pp. 257-337 ש. 
Com base no exposto, observa-se que os estudos precursores sobre as epistemologias africanas e afrodiaspóricas foram desenvolvidos pela antropologia, a história e a filosofia. Entretanto, embora no período descrito se fizesse vigente enquanto problemática a ser analisada, a questão racial e as epistemologias afrodiaspóricas foram incorporadas no bojo interpretativo da sociologia latino-americana? E quais suas contribuições no fomento do pensamento social crítico e na construção de um método interpretativo para essa ciência? Esses questionamentos acompanham o reconhecimento de que a história social latino-americana é permeada por tensões sociorraciais e interétnicas que afetaram e afetam, drasticamente, os povos originários, os povos tradicionais e a população negra em toda a região e, por conseguinte, deveriam merecer um lugar de análise no fazer sociológico latino-americano.

O Brasil adentra o processo de desenvolvimento da sociologia por volta de 1930, período em que a sociologia brasileira vai se formulando e traçando suas vertentes teóricas e metodológicas para a interpretação dos fenômenos sociais inerentes à formação sociocultural, econômica e política do Brasil. É a partir dessa época que são publicadas uma variedade de obras que rapidamente adquirem um reconhecimento intelectual na análise sociológica não só do Brasil, mas de outros países da região, escritas por pesquisadores, em sua maioria, homens, de classe média alta e brancos.

No cerne do debate sociológico brasileiro, a questão racial e a mestiçagem emergem entre as temáticas de relevo para a compreensão da sociedade brasileira, sobretudo nas obras de Gilberto Freyre-especialmente Casa-grande \& Senzala: formação da família brasileira sob o regime da economia patriarcal (1933) - e Florestan Fernandes - com destaque para a obra A integração do negro na sociedade de classes (1964). O primeiro mais atento a demarcar esse debate no legado positivo da mestiçagem no Brasil, a contrapelo da crítica do segundo, mais preciso na ênfase dada ao lugar subalterno imposto ao negro na sociedade brasileira. Em Casa-Grande \& Senzala, embora Freyre reconhecesse as contradições ou antagonismos existentes e intrínsecos à escravidão, julgou que o próprio 
processo de miscigenação, enquanto fenômeno sociocultural e histórico, permitiu transcendê-las.

Florestan Fernandes foi um intelectual fundador da sociologia crítica e militante, deixou seu contributo sobre as relações raciais entre brancos e negros, e sobre os índios. A obra A integração do negro na sociedade de classes, publicada logo após o golpe militar em 1964, tornou-se um importante referente na abordagem crítica da questão racial no Brasil, sobretudo por interpelar a falsa ideia de uma democracia racial ao revelar o quanto a sociedade brasileira era desigual social e racialmente.

De acordo com o autor, "a sociedade brasileira largou o negro ao seu próprio destino, deitando sobre seus ombros a responsabilidade de se reeducar e de se transformar para corresponder aos novos padrões e ideais de ser humano". ${ }^{27}$ Isto é, o ex-escravizado, na condição de "liberto" pela falsa abolição, se defrontou com a competição do imigrante europeu no mercado de trabalho, ainda que não tenha sido preparado para sua inserção no novo regime. Florestan coloca em evidência a violência, o preconceito e a segregação contra os negros como elementos fundamentais na formação da sociedade brasileira. Apesar de não tratar diretamente sobre racismo, seu livro revolucionou a compreensão do racismo no Brasil, por contestar a "democracia racial", colocando a análise sociológica da questão racial na perspectiva do oprimido, sob a ótica da "senzala" em relação à "casa-grande” sem, contudo, mistificar a senzala, junto com as comunidades negras segregadas. Nessa direção, desenvolveu uma interpretação da realidade social do negro tomando como base a necessidade de uma "segunda abolição". ${ }^{28}$

Em 1972, Florestan Fernandes escreveu sobre as desigualdades raciais no Brasil, elucidando que eram resquícios de um passado escravagista e que, com o passar do tempo, essas desigualdades tenderiam a desaparecer. Porém, isso não aconteceu com o passar dos anos, ao contrário,

27 Florestan Fernandes, A integração do negro na sociedade de classes: o legado da “raça branca”, São Paulo: Globo, 2008, p. 35.

28 Fernandes, A integração do negro. 
se intensificou, de forma acentuada e desordenada. Apesar de Fernandes ser sensível à situação do negro na sociedade de classes, sua abordagem sobre a questão racial não adentrava, suficientemente, as implicações interseccionais intrínsecas a esses dois pilares que estruturam a sociedade, quais sejam, raça e classe social. Consideramos central analisar o lugar da raça para o reconhecimento do racismo estrutural como definidor de posições políticas, sociais, acadêmicas e econômicas em todas as relações sociais. No entanto, mesmo que ele não tenha concordado com a ideia de inferioridade negra, "ao afirmar que o negro escravizado acabou deformado, acaba por atribuir inferioridade ao negro”. ${ }^{29}$

Portanto, o trato da questão racial e da situação do negro tinham seu lugar de relevância no âmbito da sociologia brasileira. Não por acaso, afinal o país teve um dos mais duradouros regimes escravocratas da região, quase quatro séculos de existência, acarretando contradições profundas que atravessam seu imaginário social e a natureza das relações sociais, plausíveis de uma interpretação sociológica.

Isso coloca o Brasil na condição de pioneiro em termos de uma abordagem da questão racial no âmbito da sociologia latino-americana e, sempre que esse objeto de análise é destacado nas pesquisas da área, estão em evidência os autores brasileiros, o que sugere a ausência ou invisibilização de produções correlatas nos demais países da região. No caso brasileiro, é sabido que a questão racial está presente nos círculos intelectuais nacionais como questão premente desde meados do século XIX, quando as teorias raciais e evolucionistas aportaram por estas paragens. A mistura racial, o atraso, o estigma, a eugenia e o "resgate da nação" são problemáticas que suscitaram intensos debates e influenciaram, sobremaneira, a luta em favor do abolicionismo, bem como as políticas públicas voltadas para as camadas populares compostas por ex-escravos e imigrantes brancos europeus, já no século XX. Portanto, tratar do

29 Maria Aparecida Silva Bento, "Branqueamento e branquitude no Brasil” in Iracy Carone e Aparecida Maria Silva Bento (orgs.), Psicologia social do racismo - estudos sobre branquitude e branqueamento no Brasil (Petrópolis: Vozes, 2002), pp. 1-30. 
pensamento social brasileiro é discutir a centralidade do problema racial na composição da nação brasileira.

As primeiras análises de corte sociológico no Brasil acompanham o processo de consolidação das ciências sociais em toda a região latino-americana. Em nosso caso, o primeiro passo é dado com a criação da Escola Livre de Sociologia e Política, em 1933. Por volta de 1950, se estende esse processo à maioria dos países do subcontinente sul-americano e começam a ser produzidos trabalhos de alta qualidade teórica e metodológica, de autores como Virgínia Bicudo, Gino Germani, Florestan Fernandes, Alberto Guerreiro Ramos, Clóvis Moura, Lélia Gonzalez, Pablo Casanova, Orlando Fals Borda, Aníbal Quijano, entre outros e outras intelectuais, o que demarca a maturidade de nossa teoria social. Paralelo a isso, nos estudos sobre economia são registradas as notáveis contribuições dos pensadores da Cepal de forma interdisciplinar, que comporão os trabalhos da vertente da "teoria da dependência". Para Marini,

a difícil gestação de uma ciência social crítica, centrada na problemática de nossas estruturas econômicas, sociais, políticas e ideológicas, havia finalmente concluído. A partir dali a produção teórica latino-americana impressionará, por sua riqueza e originalidade, aos grandes centros produtores de cultura, na Europa e nos Estados Unidos, revertendo o sentido do fluxo das ideias que havia prevalecido no passado. Novas e ricas correntes de pensamento surgirão em seguida sobre solo fertilizado, abrindo amplas perspectivas para a compreensão integral de nossa realidade. ${ }^{30}$

Por se tratar de uma relação dialética, depois de mais de meio século de desenvolvimento da sociologia, foram criadas na América Latina "informação e metodologias de investigação que, somadas a uma considerável massa crítica, nos permitem falar de uma sociologia

30 Marini, Dialética da dependência, p. 265. 
latino-americana”. ${ }^{31}$ A sociologia, como disciplina científica, especializou-se acentuadamente em oferecer respostas à totalidade da realidade social e seus desdobramentos em vigência, contribuindo na adequação e refinamento do instrumental teórico-metodológico que se aplica ao objeto estudado. Esse amadurecimento da disciplina assinala aos sociólogos um compromisso de assumir, junto à sociedade, o estudo e a pesquisa para propor instrumentos capazes de vislumbrar não só interpretações de determinados fenômenos, mas também apontar possíveis soluções e horizontes de transformação social. No largo da história, a sociologia,

ainda tem muito que lutar contra a ação das tradições do pensamento social alienada. Ela necessita reexaminar criticamente a problemática herdada do passado, quando realizava abordagens histórico-jurídicas, e passar a conceber os problemas e fenômenos que caem no seu campo segundo os recursos metodológicos e teóricos disponíveis. ${ }^{32}$

Sobre essa questão, Guerreiro Ramos adverte que o trabalho sociológico é dependente da ciência estrangeira, "de modo mecânico, servil, sem dar-se conta de seus pressupostos históricos originais, sacrificando seu senso crítico ao prestígio que lhe granjeava exibir ao público leigo o conhecimento de conceitos e técnicas importadas”. ${ }^{33}$ Isso demonstra que o debate aberto por esses sociólogos, em meados do século XX, evidenciava o quanto a sociologia, em perspectiva latino-americana, permanecia adepta do caráter universal dos cânones europeus. Ramos, em sua obra A Redução Sociológica (1958), salienta três sentidos básicos da redução sociológica, quais sejam:

(1) redução como método de assimilação crítica da produção sociológica estrangeira; (2) redução como atitude parentética, isto é, como adestramento cultural do indivíduo, que o habilita a transcender,

31 Marini, Dialética da dependência, p. 266.

32 Ianni, Sociologia da sociologia, p. 132.

33 Ramos, A redução sociológica, pp. 8-9. 
no limite do possível, os condicionamentos circunstanciais que conspiram contra sua expressão livre e autônoma; (3) redução como superação da sociologia nos termos institucionais e universitários em que se encontra. A sociologia é ciência por fazer. ${ }^{34}$

No âmbito de uma "sociologia das reputações intelectuais", 35 a recepção intelectual a Guerreiro Ramos, em particular de sua obra A Redução Sociológica, esteve marcada por duras críticas. Destaca-se a crítica feita por Jacob Gorender ao subjetivismo da ideologia nacionalista, que desconsideraria as contradições de classe; também as críticas recebidas acerca de suas teses sobre o negro brasileiro e seu protagonismo na esfera pública, sobretudo no debate intelectual travado com Luiz Aguiar da Costa Pinto em torno do estatuto da questão racial no Brasil e, finalmente, a crítica recebida de Florestan Fernandes em torno de suas teses nacionalistas. ${ }^{36}$ Por mais que Ramos tenha sido mal interpretado e sofrido críticas devido a esta obra, sua ponderação feita, criticamente, acerca do caráter dependente do pensamento sociológico na realidade nacional, nos permite inferir que a consciência crítica no fazer sociológico emerge não só do rigor metodológico, mas também do olhar sensível e do pensar crítico acerca dos sentidos históricos das condições sociais e estruturais e suas contradições.

Para o caso latino-americano, assumir essa sociologia por fazer deveria ter como premissa a máxima de José Martí de pensar com cabeça própria, isto é, não aderir permanentemente à “importação” de categorias de alhures, muitas vezes forçadamente usadas para interpretar nossa realidade social. Essa sociologia por fazer também nos exige a capacidade e a criatividade de produzir ideias. Isso não significa uma ruptura epistemológica radical, de menosprezo pelo aporte teórico-metodológico proveniente da Europa, menos ainda a ausência de diálogos com a produção intelectual e

34 Ramos, A redução sociológica, p. 11.

35 João Marcelo E. Maia. "Reputações à brasileira: o caso de Guerreiro Ramos", Sociologia \& Antropologia, v. 2, n. 4 (2012), pp. 265-291.

36 Maia, “Reputações à brasileira”, p. 270. 
acadêmica do norte global. Ao contrário, a nossa busca é por um diálogo horizontal em que se respeite as ontologias e as epistemologias dos diferentes povos enquanto matrizes de construção do conhecimento. Em sintonia com Ramos, “à assimilação literal e passiva dos produtos científicos importados ter-se-á de opor a assimilação crítica desses produtos. Por isso, propõe-se aqui o termo 'redução sociológica’ para designar o procedimento metódico que procura tornar sistemático a assimilação crítica”. ${ }^{37}$

Sendo assim, Ramos, de forma crítica, nos mostra a subordinação desse pensamento social às limitações estruturais advindas de fora, no caso do Brasil, destacando que "não há, porém, uma redução sociológica apenas da produção sociológica propriamente dita”. ${ }^{38}$ Na concepção do autor, existem várias formas de redução sociológica, estendidas ao direito, à economia, à política, à antropologia cultural, à psicologia, à filosofia, e às ciências em geral, pois a redução no sentido restrito da sociologia,

é uma atitude metódica que tem por fim descobrir os pressupostos referenciais de natureza histórica, dos objetos e de fatos da realidade social. A redução sociológica, porém, é ditada não somente pelo imperativo de conhecer, mas também pela necessidade social de uma comunidade que, na realização de seu projeto de existência histórica, tem de servir-se da experiência de outras comunidades. ${ }^{39}$

Com base no debate aberto por esses intelectuais, consideramos que a sociologia latino-americana deveria assumir como uma de suas tarefas o aprofundamento das pesquisas relacionadas à questão racial e à diáspora negra, especialmente por ser parte constituinte do processo histórico de nossa formação social como região, ou seja, é basilar em nossa existência histórica. Entretanto, no âmbito dos espaços de difusão e intercâmbio da produção científica relacionada à sociologia latino-americana,

37 Ramos, A redução sociológica, p. 68.

38 Ramos, A redução sociológica, p. 68.

39 Ramos, A redução sociológica, p. 71. 
a propósito dos congressos articulados pela Associação Latino-Americana de Sociologia (ALAS) e pelo CLACSO, não só perdura o caráter dependente e subordinado em relação à Europa e à América do Norte, evidenciado na hegemonia de determinados intelectuais do norte global sempre convidados para a abertura desses eventos ou para as principais conferências, como também é incipiente o espaço dado às epistemologias e à intelectualidade negras, ainda restritas aos artigos que se apresentam nos grupos de trabalho desses congressos.

Também é inevitável não nos questionarmos sobre o lugar da questão racial, do negro e da diáspora africana no âmbito das pesquisas da sociologia latino-americana e de sua circulação no contexto contemporâneo. Essa inquietação acompanha uma segunda: quando a sociologia latino-americana e os congressos da área darão mais respaldo e visibilidade aos escritos de intelectuais negros e negras, reconhecendo-os como sujeitos construtores de conhecimento? Diante do exposto, convém questionar sobre a invisibilização do negro na história da ciência e, em particular da sociologia latino-americana, como prática de racismo epistêmico e acadêmico.

Para o caso do CLACSO, observamos algumas iniciativas muito recentes no âmbito da formação acadêmica, a propósito da $1^{\circ}$ Escuela Internacional de Posgrado: "Más allá del decénio internacional de los pueblos afrodescendientes”, realizada em outubro de 2019 em Cuba e organizada pela parceria entre o Centro de Investigaciones Psicológicas y Sociológicas de Cuba, a Cátedra de Estudios sobre Afrodescendencias Nelson Mandela, e os Grupos de Trabalho CLACSO Afrodescendencias y Propuestas Contrahegemónicas e Epistemologías del Sur. Outra iniciativa da Rede de Pós-Graduação do CLACSO é a Especialización en Estudios Afrolatinoamericanos y Caribeños (2019-2020), além de alguns seminários virtuais, com destaque para os seguintes: “Feminismo Negro”, “Racismo y Nación”, “Raza/Negritud y Humanidad” e "Traducciones interculturales entre América Latina, el Caribe y África”, realizados em 2019. Entretanto, é fundamental destacar que estas são tenras iniciativas, o que reforça nosso argumento acerca do caráter 
marginal e marginalizado das epistemologias negras e da diáspora na história do desenvolvimento da sociologia latino-americana.

\section{O negro na história da sociologia latino-americana}

Conforme apresentado, o debate sobre a questão racial e as epistemologias africanas e afrodiaspóricas emergem no contexto latino-americano e caribenho em outras áreas do conhecimento e, tardiamente, tornam-se um fenômeno sociológico de relevo, sobretudo para identificar e analisar as interfaces da presença negra e afrodiaspórica no imaginário social da região. O Brasil, mais uma vez, é pioneiro na abordagem da questão racial no âmbito da sociologia latino-americana. Nos anos 1950, após a $2^{\mathrm{a}}$ Guerra Mundial, a Unesco patrocinou uma série de pesquisas e investigações em regiões economicamente tradicionais, tendo em vista o campo das interações raciais. Vale frisar que, quando subsidiou os estudos sobre as relações raciais no Brasil, a Unesco estava interessada em obter elementos que lhes permitisse difundir as características modelares de uma "democracia racial”, deixando à margem uma análise aprofundada da questão racial em si. No âmbito dos estudos acerca da situação do negro e da questão racial no Brasil, foram Roger Bastide e Florestan Fernandes, na USP, os que obtiveram maior visibilidade e reconhecimento entre os pesquisadores envolvidos nos estudos feitos no projeto. ${ }^{40}$ Grosso modo, a Unesco,

foi criada tendo como um de seus principais objetivos tornar inteligível o conflito internacional e sua consequência mais perversa, o Holocausto.

A persistência do racismo, especialmente nos EUA e África do Sul, o surgimento da Guerra Fria e o processo de descolonização africana e asiática mantiveram a atualidade da questão racial. A Unesco,

40 Ianni, Sociologia da sociologia; Marcos Chor Maio, “O projeto Unesco e a agenda das Ciências Sociais no Brasil dos anos 40 e 50”, XXII Encontro Anual da Anpocs, GT: Pensamento Social no Brasil (Caxambu, 1998), pp. 1-27. 
em perspectiva igualitária e universalista, estimulou a produção de conhecimento científico a respeito do racismo, abordando as motivações, os efeitos e as possíveis formas de superação do fenômeno. ${ }^{41}$

No contexto pós-genocídio nazista, o Brasil obteve notoriedade latino-americana quanto ao panorama das relações raciais e étnicas. O sociólogo francês Roger Bastide, na virada da década de 1940 para 1950, participou do $1^{\circ}$ Congresso do Negro Brasileiro, no Rio de Janeiro, representando a França. O referido evento foi patrocinado pelo Teatro Experimental do Negro (TEN), uma associação político-cultural sob a liderança de Abdias do Nascimento, tendo como fito aproximar intelectuais e cientistas sociais do movimento negro, no intento de aliar trabalho acadêmico e intervenção política. Essa articulação entre a pesquisa e a ação política visava oferecer alternativas para a redução das disparidades socioeconômicos existentes entre brancos e negros, não resolvidas no pós-abolição. ${ }^{42}$ Foi neste mesmo evento que o sociólogo e militante do TEN, Guerreiro Ramos, sugeriu que o $1^{\circ}$ Congresso do Negro Brasileiro buscasse sensibilizar o governo no sentido de convencer a Unesco a patrocinar um Congresso Internacional de Relações de Raça, com o foco no desenvolvimento de pesquisas vinculadas às sugestões práticas, evitando estudos meramente descritivos. Porém, a proposta suscitada por Ramos contemplava apenas uma parte do interesse da agenda internacional. ${ }^{43}$

É interessante observar que, nesse período, a Escola Livre de Sociologia e Política (ELSP) e a Faculdade de Filosofia, Ciências e Letras (FFCL) da USP “eram instituições científicas que gozavam de maior prestígio junto à Unesco" e, no caso da ELSP, tinha em seu corpo docente um dos possíveis sociólogos a cargo da pesquisa sobre as relações raciais no Brasil, o estadunidense Donald Pierson. Entretanto, como o

41 Maio, “O projeto Unesco”, pp. 3-4.

42 Maio, “O projeto Unesco”, p. 9.

43 Maio, “O projeto Unesco”, p. 9. 
sociólogo já se dedicava ao desenvolvimento de outra pesquisa, sugeriu Oracy Nogueira, então professor da ELSP, para participar no projeto. ${ }^{44}$

Sobre esta questão, é importante destacar que Virgínia Leone Bicudo, socióloga e psicanalista brasileira, negra, foi a única mulher a obter o grau de bacharel em ciências políticas e sociais em 1938, na ELSP. Em 1945, antes mesmo do projeto da Unesco eleger o Brasil como laboratório sociológico de investigação, Bicudo defendia sua dissertação de mestrado sob a orientação de Donald Pierson, cujo título era Estudo de atitudes raciais de pretos e mulatos em São Paulo, apresentada na primeira turma de pós-graduação em ciências sociais em todo Brasil. Virgínia Leone Bicudo desenvolveu um trabalho pioneiro dentro da área dos estudos raciais na ELSP, juntamente com seus colegas Oracy Nogueira e Gioconda Mussolini. Os três foram os primeiros estudantes de pós-graduação em sociologia e antropologia da ELSP. ${ }^{45}$

É notório que nesse universo invariavelmente branco e masculino, as mulheres, sobretudo mulheres negras, são deslegitimadas deste fazer científico, de ocupar este espaço, e são totalmente silenciadas e invisibilizadas. Um exemplo disso foi a preferência por Nogueira na substituição de Pierson para execução da pesquisa no projeto Unesco, um sociólogo homem e branco, e não foi cogitado o nome de Virgínia Bicudo, uma socióloga negra, que inaugurou na academia o debate sobre o racismo, desenvolvendo um trabalho pioneiro no terreno das relações raciais. Aliás, no campo da sociologia, Virgínia Leone Bicudo foi a primeira mulher a desenvolver pesquisas na área das relações étnico-raciais na América Latina, e a primeira psicanalista negra no Brasil. No entanto, seu nome, seu protagonismo e sua história tornaram-se invisíveis no seio da produção intelectual do campo sociológico, renegada ao esquecimento, ao desconhecimento e à invisibilidade no campo acadêmico. Não apenas

44 Maio, “O projeto Unesco”, p. 15.

45 Janaína Damaceno, “Os segredos de Virgínia: intelectuais negras e relações raciais em São Paulo dos anos 1940-1950” in Joseline Silva e Amauri Pereira (orgs.), O Movimento de Mulheres Negras: escritos sobre os sentidos de democracia e justiça social no Brasil (Belo Horizonte: Nandyala, 2014), pp. 41-66. 
a autora em questão, mas diversas outras "Virgínias” que fazem parte desse espaço de silenciamentos. É sobre essas tensões raciais no universo do saber que nos delineamos, ou seja, no que tange à variável racial na história da ciência no Brasil, demonstrando o racismo com suas diversas faces no país da tão propalada democracia racial. Isso demonstra que,

o trabalho acadêmico também é eivado pela conquista de hegemonia de poder. Quando se afirma que o pensamento predominante nos anos 1940 era o da não existência de preconceito racial no Brasil, acaba-se apenas por refletir essa visão hegemônica do período sem complexificá-lo, sem mostrar a existência de um panorama sobre as relações raciais mais amplo. Então, a reaparição do trabalho de Virgínia Bicudo, hoje, não se trata de uma descoberta. Trata-se de um movimento em que não é mais possível ocultá-la. ${ }^{46}$

É fato que nos principais trabalhos produzidos sobre as relações sociais no Brasil praticamente não há referência a Virgínia Bicudo. Aliás, sequer ela é mencionada entre a intelectualidade pioneira nos estudos da questão racial e do racismo na América Latina. Ao financiar o desenvolvimento de pesquisas, a Unesco tratava de demarcar uma agenda de estudos internacionais direcionada à comprovação científica de algumas hipóteses que já sustentava. Naquele momento, era mobilizada entre alguns pesquisadores a ideia da não existência do preconceito racial no Brasil, mas sim situações de preconceito de classe, não de cor. Donald Pierson, inclusive, foi um dos cientistas sociais que corroborou com essa premissa, afirmando a inexistência de preconceito racial e de consciência racial entre negros baianos, em seu estudo Negroes in Brazil: a study of race contact at Bahia (1942). ${ }^{47}$

Em contrapartida, as pesquisas desenvolvidas por Virgínia Bicudo e Oracy Nogueira, ainda que ambos estivessem sob orientação de

46 Damaceno, “Os segredos de Virgínia”, p. 62.

47 Damaceno, “Os segredos de Virgínia”, p. 62. 
Pierson, contribuíram com a desmistificação da inexistência de preconceito racial entre brancos e negros aferida por seu orientador. Em virtude das constatações resultantes do rigor metodológico e contundência do argumento em torno do preconceito racial no Brasil, a questão racial foi retomada com Roger Bastide e Florestan Fernandes, entre outros intelectuais pesquisadores. Ao adotarem essa estratégia, tanto Bicudo como Nogueira se distanciam da interpretação proferida por Pierson e, assim, constroem um novo modelo analítico diferenciado para pensar a questão racial e o racismo. Para Oracy Nogueira, o preconceito racial não estava atrelado à questão de origem (ascendência), mas ao preconceito de marca (aparência). E Virgínia Bicudo demonstrou, por meio de sua pesquisa com pessoas negras da Frente Negra Brasileira, que mesmo o negro ascendendo economicamente, não se tornava isento do preconceito racial, tampouco eliminava a distância social entre brancos e negros, pelo contrário, a deixava mais demarcada. ${ }^{48}$

Com base no exposto, destacamos a relevância da realização e da circulação de pesquisas fora dos ditames acadêmicos sacralizados, nutridas por intelectuais, sociólogos e antropólogos que levem em conta o padrão de vida de brancos e não brancos, incluindo "salários, tipos de ocupação e, de modo mais abrangente, a influência da variável racial na competição no mercado de trabalho, bem como a interferência da religião na dinâmica das relações raciais”. ${ }^{49}$ Isto porque cabe ao sociólogo investigar e desvendar os fundamentos da estrutura sociorracial, indicando os mecanismos que reproduzem o racismo.

Neste ensejo, ratificamos que os autores discutidos compõem uma geração de intelectuais, cujas trajetórias estão fortemente vinculadas ao processo de institucionalização e amadurecimento das ciências sociais no Brasil, que também acontecia nos demais países da região. Os cientistas sociais envolvidos com a realidade latino-americana desenvolveram trabalhos, ensaios, artigos e livros de cunho sociológico, cujas contribuições

\footnotetext{
48 Damaceno, “Os segredos de Virgínia”, p. 64.

49 Maio, “O projeto Unesco”, p. 13.
} 
teóricas estão permeadas pela reflexão crítica e científica. Entretanto, conforme apresentamos no início deste artigo, os eixos temáticos de interesse no âmbito das pesquisas próprias da sociologia latino-americana davam maior ênfase à perspectiva cultural, das instituições políticas e da democracia, dos problemas cruciais do caráter subdesenvolvido e dependente da América Latina, entre outros que permitissem uma interpretação da “incapacidade da ‘sociedade fechada' de modernizar-se, ou dinamizar-se, segundo a tendência e o ritmo dominantes na 'sociedade aberta'”. ${ }^{50}$ Devido a razões históricas e culturais, a questão racial e das epistemologias africanas e afrodiaspórica não figurava como um elemento de relevo no escopo mais amplo da sociologia na região.

Ao longo da história da América Latina houve, e ainda persiste nas ciências sociais, a predominância do racismo científico. O sociólogo Karl Monsma ${ }^{51}$ adverte que precisamos abordar a racialização das instituições sociais (as escolas, as polícias, as universidades, as igrejas e a família), bem como a internalização do racismo como um aspecto do "habitus racial”, tratando os integrantes dessa categoria de maneira diferenciada. Com base nesse argumento, é sabido que

a intelectualidade brasileira, em meados do século XIX e início do século XX, respirava ares europeus. As teorias científicas da última moda recheavam as análises dos brasileiros sobre sua sociedade e sobre o continente americano desbravado pelos impérios ibéricos. O racismo científico encontra solo fértil entre nossos intelectuais, uma vez que engatinhávamos na elaboração de um pensamento próprio e original sobre a composição de nossa sociedade e creditávamos à mestiçagem do povo americano as causas de suas mazelas políticas, econômicas e sociais. ${ }^{52}$

50 Ianni, Sociologia da sociologia, p. 53.

51 Karl Monsna, A reprodução do racismo: fazendeiros, negros e imigrantes no oeste paulista - 1880-1914, São Carlos: EdUFSCar, 2016, p. 19.

52 Gislania de Freitas Silva e Larissy Leal Matias, "Parasitismo social: chave analítica para a obra de Manoel do Bonfim”, Tensões Mundiais, v. 12, n. 23 (2016), pp. 101-103. 
Importante destacar que os 380 anos de escravidão no Brasil, articulados à problemática estrutural do analfabetismo, contribuíram, veementemente, com a negação do universo escolar e universitário para a população negra. Na realidade, a negação do direito à educação e à escola às populações indígenas, negras, camponesas, de comunidades tradicionais, entre outras, é uma problemática histórica de toda a América Latina. Tal fato acarretou não só a presença majoritária de brancos nas carreiras científicas, como também uma naturalização desse espaço ocupado como legítimo, sob o disfarce de uma falsa democracia racial que tentava ocultar o racismo científico. Resultado desse processo histórico é a ausência de "um lugar de fala" 53 na análise em torno da questão racial e a negação e invisibilização daqueles que foram pioneiros nesse debate no âmbito das ciências sociais, fato que perdura até hoje em nossas universidades.

Um exemplo disso é o pouco destaque dado às teorias e às pesquisas desenvolvidas por pesquisadores negros e negras, haja vista que no campo das ciências sociais no Brasil não se tem o hábito de estudar autores como Virgínia Bicudo, Lélia Gonzalez, Beatriz Nascimento, Alberto Guerreiro Ramos, Clovis Moura, Abdias do Nascimento, Kabengele Munanga, Sueli Carneiro, entre outros. E no contexto das ciências sociais ou da sociologia latino-americana seria distinto? Infelizmente, não, porque além do racismo científico, a questão racial e suas interfaces permanecem ausentes dos grandes debates contemporâneos dessa área do conhecimento, circunscritas aos espaços de formação política dos diferentes movimentos negros, que disputam a narrativa teórica sobre sua própria história, dentro e fora das universidades e demais círculos do debate acadêmico. Essa situação persistente contribui para o silenciamento e invisibilização de saberes não eurocêntricos. Diante disso, Andrews sinaliza que

a resposta das elites e dos intelectuais brasileiros a tais ideias foi ambivalente. Por um lado, as teorias raciais chegam no Brasil imbuídas

53 Djamila Ribeiro, O que é lugar de fala? Belo Horizonte: Letramento; Justificando, 2017. 
do grande prestígio da ciência europeia, e também harmonizavam-se com as noções nativas brasileiras da superioridade racial dos brancos. Por outro, a vigorosa condenação da mistura racial por parte do racismo científico constituiu devastadora crítica da sociedade brasileira. ${ }^{54}$

Sob essa ótica, nos anos seguintes, a discussão das teorias e desigualdades raciais tiveram continuidade nas décadas de 1970 e 1980, gerando uma nova onda de pesquisas no intuito de descortinar a situação racial brasileira, alavancada por diferentes intelectuais, tais como Florestan Fernandes, Octavio Ianni, Darcy Ribeiro, Oracy Nogueira, Clóvis Moura, Jacob Gorender, Joel Rufino dos Santos, Lélia Gonzalez, Carlos Hasenbalg, entre outros. Algumas pesquisas realizadas nesse período visavam superar o mito da democracia racial, representada na obra Casa-Grande \& Senzala, de Gilberto Freyre, que mantinha uma hegemonia inquestionável na elaboração de uma interpretação sociológica sobre a escravidão. Nesse sentido, do ponto de vista da produção acadêmica, foram feitas pesquisas acerca das desigualdades raciais no mercado de trabalho no período pós-abolição e seus desdobramentos, bem como, os desníveis de renda e acesso à educação entre brancos e negros. ${ }^{55} \mathrm{E}$ na década de 1990, no governo de Fernando Henrique Cardoso, a partir do momento que foi admitida oficialmente a existência de preconceito e discriminação racial na sociedade brasileira, alguns intelectuais do país desenvolveram importantes estudos sobre as relações raciais. Esse movimento, consolidado nos anos 1990, contou, fundamentalmente, com a contribuição do ativismo negro para o debate sobre a questão racial nas ciências sociais. ${ }^{56}$

Estes pesquisadores criaram nódulos de resistência e tensão no emaranhado acadêmico e inauguraram um fazer científico em que a

54 George Reid Andrews, "Democracia racial brasileira 1900-1990: um contraponto americano”, Estudos Avançados, n. 11 (1997), p. 95-115.

55 Ângela Figueiredo e Ramón Grosfoguel, "Racismo à brasileira ou racismo sem racistas: colonialidade do poder e a negação do racismo no espaço universitário”, Sociedade e Cultura, v. 12, n. 2 (2009), pp. 223-234.

56 Figueiredo e Grosfoguel, “Racismo à brasileira”, p. 223. 
pesquisa começa a extrapolar os muros da academia, ou melhor, adentra-se esse espaço para disputar a autoridade epistêmica sobre os processos históricos inerentes à questão racial. Alguns pesquisadores negros e negras que começam a entrar nas universidades passam a analisar criticamente os fatos, expondo e questionando os problemas sociorraciais decorrentes do período escravista e suas consequências na consolidação do racismo, com o intuito de que estes sejam solucionados. Disputar a universidade constitui um passo histórico fundamental para que se reconheça que “o negro como ser pensante e intelectual atuante articula uma ideologia na qual unem-se a ciência e a consciência”. ${ }^{57}$ Ainda que sem uma consciência plenamente elaborada, havia um posicionamento crítico no processo de radicalização epistemológica, diante de um quadro social e intelectual acostumado a ver os negros apenas como objeto de estudo e não como sujeito ativo na construção e elaboração do conhecimento científico. ${ }^{58}$

Nessa direção, no que remete à questão racial, Octavio Ianni, deixou seu contributo científico, ao pesquisar as relações raciais em São Paulo, assegurando que "a presença do negro na história social brasileira desvenda perspectivas fundamentais para a construção do ponto de vista crítico na sociologia, nas ciências sociais e em outras esferas do pensamento brasileiro". ${ }^{59}$ Tanto Florestan Fernandes como Octavio Ianni elaboram contribuições significativas para o movimento negro em suas trajetórias intelectuais, permitindo uma análise precisa das dimensões da branquitude. Florestan Fernandes discute a adesão dos setores brancos a "padrões tradicionalistas" e aponta que o apego do branco à estrutura social herdada da escravidão constituiu um dos problemas para a integração social do negro. É válido destacar que, na década de 1980, Lélia Gonzalez analisa o caráter sofisticado do racismo latino-americano devido à imposição da ideologia do branqueamento que define e impõe um lugar

57 Clóvis Moura, Sociologia do negro brasileiro, São Paulo: Ática, 1988, p. 31.

58 Moura, Sociologia do negro brasileiro, p. 41.

59 Ianni, Sociologia da sociologia, p. 37. 
social para negros e indígenas. ${ }^{60}$ Contemporaneamente, esses debates nos auxiliam na compreensão do papel que o branco ocupou e ainda ocupa como sujeito branco, na perpetuação das desigualdades raciais, bem como a deformação provocada pela branquitude no corpo negro. ${ }^{61}$

Foi a partir dos trabalhos sobre o negro que Florestan Fernandes deixou de ser neutro em relação à sociedade de classes e passou a pesquisar os problemas que afetavam particularmente "os de baixo”, uma vez que transformou o estudo sobre o negro numa militância a favor do negro. Em vez de estudar os negros como objeto de análise, conforme se fazia até então, ele e Roger Bastide decidiram mobilizar a comunidade negra para participar da pesquisa como sujeito, juntamente com outros pesquisadores. Ainda que plausível, tal atitude, no sentido de um fazer ciência para a causa popular, causou um forte descontentamento e impacto na universidade, com reações nada amigáveis dos professores da instituição.

No que concerne aos racistas científicos ortodoxos, sobretudo aqueles que atuavam no início do século XX, estes “afirmavam a superioridade da herança racial branca, mas também defendiam que a herança era enfraquecida pela mistura com raças inferiores". ${ }^{62}$ Este racismo cientificista, vorazmente aceito pela elite cultural, inspirou as concepções e pensamentos de intelectuais como Euclides da Cunha, Raimundo Nina Rodrigues, Sílvio Romero e Oliveira Viana, que tornaram-se conhecidos no seio acadêmico como defensores ardorosos dessas ideias. ${ }^{63}$

Estes intelectuais assumiam um posicionamento "embebido e deslumbrado pela ciência oficial europeia que predominava no seu tempo e via o negro como biologicamente inferior, transferindo pra ele as causas do nosso atraso social”. ${ }^{64}$ Durante décadas isso influenciou negativamente

60 Lélia Gonzalez, “A categoria político-cultural de amefricanidade”, Tempo Brasileiro, v. 92, n. 93, 1988, pp. 69-81.

61 Bento, "Branqueamento e branquitude no Brasil”, p. 22.

62 Andrews, "Democracia racial brasileira”, p. 97.

63 Moura, Sociologia do negro brasileiro, p. 44; Jacob Gorender, A escravidão reabilitada, São Paulo: Expressão Popular; Fundação Perseu Abramo, 2016, p. 13.

64 Moura, Sociologia do negro brasileiro, p. 18. 
o pensamento social brasileiro, e ainda na atualidade nos deparamos com resquícios desse racismo científico que continua em pleno vigor em toda a América Latina. Nesse período, nos estudos desenvolvidos por estes pesquisadores, denominados como “estudos africanistas”, as análises eram feitas subordinadas a métodos que não conseguiam ou não pretendiam penetrar na essência da questão racial para, então, tentar resolvê-la cientificamente. E ao invocarem

uma imparcialidade científica inexistente nas ciências sociais, assessoram, de certa forma, embora de forma indireta, a constelação de pensamento social racista que está imbricado no subconsciente do brasileiro médio. Essa ciência, quase toda ela estruturada através de modelos teóricos e postulados metodológicos vindos de fora, abstém-se de estabelecer uma práxis capaz de determinar parâmetros conclusivos e normas de ação para a solução do problema racial brasileiro nos seus diversos níveis e implicações. ${ }^{65}$

Vale acrescentar que a geração que antecedeu a gênese da sociologia na região não tinha como mote a elaboração de um pensamento isento de preconceitos contra o negro. Na verdade, houve um desprezo pelo negro, mesmo como objeto da ciência. Esses trabalhos interpretavam o negro não como um ser socialmente situado numa determinada estrutura, ou seja, como escravizado e ex-escravizado, mas como um indivíduo de uma cultura diferente do ethos nacional. ${ }^{66}$

No plano teórico, para Moura, "é aplicado sobre a realidade do negro, como se ele fosse apenas objeto de estudo e não sujeito dinâmico de um problema dos mais importantes para o reajustamento estrutural da sociedade brasileira”. ${ }^{67}$ E esta concepção permanece no campo epistêmico contemporâneo, relacionado ao pensamento social acadêmico. Para Moura, isso se deve

65 Moura, Sociologia do negro brasileiro, pp. 17-18.

66 Moura, Sociologia do negro brasileiro, p. 41.

67 Moura, Sociologia do negro brasileiro, p. 9. 
à assimilação dos valores ideológicos de uma sociologia hermética que leva o negro a ser cobaia sociológica daqueles que dominam o campo das ciências sociais, bem como à imparcialidade científica do pesquisador, em face dos problemas raciais e sociais enfrentados pelo povo negro. ${ }^{68}$ Nessa empreitada, o negro é transformado em objeto de laboratório. Sendo assim, Moura sinaliza alguns caminhos epistemológicos aos cientistas sociais e ressalta:

não quero que exista uma sociologia negra no Brasil, mas que os cientistas sociais tenham uma visão que enfoque os problemas étnicos do Brasil a partir do negro, porque, até agora, com poucas exceções, o que se vê é uma ciência social que procura abordar o problema através de uma pseudo-imparcialidade científica que significa, apenas, um desprezo olímpico pelos valores humanos que estão imbricados na problemática que estudam. Não observam que seus conceitos teoricamente corretos (dentro da estrutura conceitual da sociologia acadêmica) coloca-os “de fora” do problema, não penetram na sua essência, são anódinos, inúteis, desnecessários à solução do problema social e racial do negro e por isso mesmo são frutos de uma ciência sem práxis e que se esgota na ressonância que o autor desses trabalhos obtém no circuito acadêmico do qual faz parte. ${ }^{69}$

Dessa forma, nas origens do pensamento social e da sociologia emergiu um circuito acadêmico de intelectuais ancorado numa ideologia colonial, racista, racializada e sacralizada dentro dos muros das universidades que, na maioria das vezes, acaba por reproduzir tais valores em seus estudos e pesquisas. No diálogo com Clóvis Moura acerca de uma sociologia do negro brasileiro, estruturada como "uma sociologia do e para o negro no Brasil”, ${ }^{70}$ argumentamos em favor de uma sociologia do negro em perspectiva latino-americana e caribenha, de modo a romper com a segregação epistêmica e social existente e persistente no âmbito

68 Moura, Sociologia do negro brasileiro, p. 60.

69 Moura, Sociologia do negro brasileiro, pp. 10-11.

70 Moura, Sociologia do negro brasileiro, p. 12. 
acadêmico em toda a região. Os estudos sobre o negro nos seus diversos aspectos têm sido mediados dentro de uma dinâmica do

aparelho ideológico de dominação da sociedade escravista, gerou um pensamento racista que perdura até hoje. Como a estrutura da sociedade brasileira, na passagem do trabalho escravo para o livre, permaneceu basicamente a mesma, os mecanismos de dominação inclusive ideológicos foram mantidos e aperfeiçoados. Daí o autoritarismo que caracteriza o pensamento de quantos ou pelo menos grande parte dos pensadores sociais que abordam o problema do negro, após a Abolição. ${ }^{71}$

Podemos assinalar, corroborando Moura, que essa subordinação ideológica, por parte dos intelectuais, assevera um posicionamento epistêmico que encontra-se parcial ou totalmente alienado de uma interpretação da realidade em perspectiva dialética, findando por assimilar e reproduzir uma ideologia de caráter colonial. Este aspecto alienante, encontrado nos escritos antropológicos, historiográficos e sociológicos, tem suas raízes sociais fincadas na estrutura despótica e racista do aparato estatal escravista. A figura do negro no imaginário social e na literatura sociológica surge exatamente para negar a "existência do negro, quer social, quer esteticamente. Toda a ação e tudo o que acontece nessa literatura tem de obedecer aos padrões brancos, ou de exaltação do índio, mas um índio distante, europeizado". ${ }^{72}$ Essa é a imagem construída do negro na literatura, descartando-o como ser humano, para então, colocá-lo como sujeito exótico e bestial. O próprio Machado de Assis, mesmo sendo um escritor que tornou-se negro no decorrer dos anos, e que por muitas vezes foi afetado pela política do embranquecimento, escreveu durante a escravidão, retratando uma realidade urbana europeia embranquecida. É nesta encruzilhada epistêmica que os estudos sobre o negro se situam. Assim,

71 Moura, Sociologia do negro brasileiro, p. 23.

72 Moura, Sociologia do negro brasileiro, p. 26. 
há encontros e desencontros entre as duas tendências: de um lado acadêmica, universitária, que postula uma ciência neutra, equilibrada, sem interferência de uma consciência crítica e/ou revolucionária, e, de outro, o pensamento elaborado pela intelectualidade negra ou outros setores étnicos discriminados e/ou conscientizados, também interessados na reformulação radical da nossa realidade racial e social. ${ }^{73}$

Contudo, reafirmamos que intelectuais negros e negras e ativistas do movimento negro vêm tecendo produções de saberes que vão na contramão das elaborações epistemológicas atravessadas pelo racismo, construídas dentro dos moldes herméticos da academia. Nesse ínterim, ressaltamos que o pano de fundo histórico-social e epistêmico é permeado por uma ideologia e uma política do branqueamento, na lógica de uma ciência advinda do norte global. A produção sociológica latino-americana também está atravessada por uma narrativa analítica eurocentrada, branqueada, que importa ideias e conceitos baseados em um modo de vida pautado no ideário civilizatório ocidental moderno e eurocêntrico. O paradigma civilizatório da sociologia produzida ao longo do século XX teve por pretensão interpretar o dito atraso social, cultural e político, com o anseio de identificar as causas que impediam as nações terceiro-mundistas de atingirem o status de modernas e civilizadas. Não se abordava, portanto, a essência das contradições históricas da questão racial.

Portanto, ao largo da história social do negro, este foi visto e tido por muitos anos como uma cobaia sociológica, e não como um sujeito social, protagonista na formação social e econômica e construtor de conhecimentos. Entendendo a questão racial a partir de uma imersão na realidade das populações negras, grupos de intelectuais negros e pesquisadores antirracistas organizaram-se a fim de estimular debates e reflexões sobre raça, para valorar, enaltecer e fomentar estudos no tocante às relações étnico-raciais e aos saberes e epistemologias negras

73 Moura, Sociologia do negro brasileiro, p. 32. 
e afrodiaspóricas. Nessa direção, no limiar do século XXI despontam, em alguns países latino-americanos e em diferentes instituições universitárias, programas de pós-graduação, grupos de pesquisa e laboratórios destinados ao aprofundamento dos estudos afro-latino-americanos, e da diáspora africana. Entre essas iniciativas, destacam-se a Maestría en Estudios Afrocolombianos, da Pontificia Universidad Javeriana, na Colômbia; o Centro de Estudios de Asia y África, d'El Colegio de México, que possui uma Maestría en Estudios de Asia y África; o Grupo de Estudios Afrolatinoamericanos, vinculado à Facultad de Filosofía y Letras da Universidad Nacional de Buenos Aires, Argentina. Ainda neste país, há a Especialización en Estudios Afro-americanos, da Universidad Nacional de Tres de Febrero (em Buenos Aires) e o Programa de Estudios Africanos do Centro de Estudios Avanzados da Facultad de Ciencias Sociales da Universidad Nacional de Córdoba. Na Venezuela, o Centro de Estudios de África, Asia y Diásporas Latinoamericanas y Caribeñas José Manuel Briceño Monzillo da Universidad de Los Andes. No Brasil, cobra relevância a criação da Universidade da Integração Internacional da Lusofonia Afro-Brasileira destinada a estudantes do Brasil, dos países africanos de língua oficial portuguesa, além de Macau e Timor Leste. Nesse mesmo país, consolida-se os Núcleos de Estudos Afro-Brasileiros e Indígenas (NEABI). Esses espaços têm por intuito alavancar perspectivas analíticas genuínas, desenvolvidas por pesquisadores e estudantes negros e não negros no universo acadêmico e em movimentos sociais. Cada região do Brasil possui um número significativo de NEABI, seja em universidades estaduais, federais ou institutos federais. De acordo com o Consórcio Nacional de Núcleos de Estudos Afro-Brasileiros(CONNEABs), existem nas regiões Norte, Nordeste, Centro-Oeste, Sudeste e Sul, respectivamente $15,32,20,36$ e 39 NEABI. ${ }^{74}$

Do mesmo modo, apontamos alguns programas de pós-graduação em relações étnico-raciais que estão em vigência. Um dos

74 Associação Brasileira de Pesquisadores/as Negros/as, Consórcio Nacional de Núcleos de Estudos Afro-Brasileiros [. 
estados que se destaca no tocante ao tema em questão é a Bahia, com dois programas de pós-graduação em ensino e relações étnico-raciais, um deles na Universidade Federal do Sul da Bahia (UFSB). ${ }^{75}$ Entre as linhas de pesquisa desse programa, se destaca a análise da implementação das leis 10.639/2003 e 11.645/2008, bem como, do Plano Nacional de Implementação das Diretrizes Curriculares para a educação das relações étnico-raciais e o ensino de história e cultura afro-brasileira e africana. O outro é o Programa de Pós-Graduação em Relações Étnico-Raciais e Contemporaneidade (PPGREC), na Universidade Estadual do Sudoeste da Bahia (Uesb).$^{76}$ Destacam-se, ainda, outros dois PPGs vinculados à Universidade Federal da Bahia (UFBA): o Programa de Pós-Graduação em História, que possui a Linha de Pesquisa "Escravidão e Invenção da Liberdade”, destinada à pesquisa em torno “da história dos negros e dos povos indígenas no Brasil, sob a escravidão e outras formas de subalternidade, do período colonial ao republicano";77 e o Programa Multidisciplinar de Pós-Graduação em Estudos Étnicos e Africanos, com duas linhas de pesquisa, a saber, Estudos Étnicos e Estudos Africanos, vinculado ao Centro de Estudos Afro-Orientais da Faculdade de Filosofia e Ciências Humanas, da Universidade Federal da Bahia. ${ }^{78}$ É importante destacar a presença de pesquisadoras e pesquisadores negros, entre o corpo docente e discente desses Programas de Pós-Graduação, os quais vêm desenvolvendo pesquisas há décadas em torno às relações étnico-raciais. Desde 2011 funciona, no Rio de Janeiro, o Programa de Pós-Graduação em Relações Étnico-Raciais no Centro Federal de Educação Tecnológica Celso Suckow da Fonseca (Cefet/RJ), tendo por foco o aprofundamento teórico no que tange à temática

75 Universidade Federal do Sul da Bahia, Mestrado em Ensino e Relações Étnico-Raciais

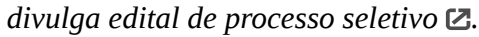

76 Universidade Estadual do Sudeste da Bahia $飞$.

77 Universidade Federal da Bahia, Programa de Pós-Graduação em História 飞.

78 Universidade Federal da Bahia, Programa de Pós-Graduação em Estudos Étnicos e Africanos $\boldsymbol{~}$. 
étnico-racial, com destaque pioneiro, sobretudo, nas áreas entre os níveis médio e técnico, graduação e pós-graduação. ${ }^{79}$

Em que pese a existência desses programas, constatamos que há uma ausência de programas de pós-graduação ligados à questão étnico-racial em universidades estaduais e federais em todos os estados do Brasil, bem como na totalidade de países da região, haja vista que não encontramos outros programas correlatos em outras universidades latino-americanas. Sinalizamos uma indagação pertinente sobre até quando essa discussão, tão relevante e necessária à comunidade negra acadêmica, vai continuar invisível e inexistindo nesse locus científico, marcadamente branco e androcêntrico. Então, ratificamos que precisamos fazer uma virada epistemológica em que essa produção se insere e descolonizar os saberes assentados em uma "história única” que situa a ciência como um atributo essencialmente branco, levando em consideração que o racismo científico influencia drasticamente o intelecto e o imaginário social dos povos colonizados. Cabe destacar que um dos fatores que contribui na falácia de que não existe preconceito e hierarquia racial é a persistência do mito da democracia racial. E que a ausência de intelectuais negros e negras nos espaços acadêmicos são reflexos do racismo estrutural emaranhado no seio das relações sociais, científicas, culturais, políticas e econômicas da sociedade latino-americana.

\section{Intelectuais negras e negros e o racismo epistêmico}

No panorama acadêmico, o intelectual negro e a intelectual negra ocupam um não lugar quando nos deparamos com as referências bibliográficas, produções intelectuais e literaturas utilizadas nas escolas ou nas ementas das disciplinas de faculdades e universidades. Quando se trata das questões

79 Centro Federal de Educação Tecnológica Celso Suckow da Fonseca, Apresentação ש. 
subjacentes ao gênero, no contexto da produção acadêmica, a mulher negra intelectual está ainda mais na invisibilidade, ou seja, na subalternidade e marginalizada no tocante ao reconhecimento intelectual. Isso nos revela o racismo epistêmico que a intelectualidade negra vivencia cotidianamente, por meio da invisibilização, do silenciamento e do apagamento dentro das instituições científicas. ${ }^{80}$

Urge a necessidade de se fazer presente a inserção de negros e negras no campo da pesquisa científica, não como objetos de estudo, mas como sujeitos que possuem e tecem conhecimentos diversos, na composição de um pensamento que rompe com as premissas epistemológicas “de uma ciência que 'nos' coloniza e ainda ‘nos’ coloca na posição de objeto do discurso científico”. ${ }^{81}$ A intelectualidade negra tem construído outros saberes e contraolhares que destoam dos parâmetros acadêmicos vigentes, por meio de práticas e conhecimentos oriundos da própria vivência racial, aliadas aos saberes adquiridos no seio da universidade, a partir de um olhar crítico e analítico para o ato de fazer ciência.

Apontamos para uma postura epistemologicamente descolonizadora, que rompe com um determinado conhecimento que mortificou, desde o surgimento da ciência e pela via do epistemicídio, uma produção de saberes não brancos e não eurocentrados. Isto é, aquele que pela via da colonização do pensamento "desqualifica e recusa os saberes que não se enquadram em seus registros”, saberes esses advindos da África e construídos com a diáspora. ${ }^{82}$ Isto resulta em uma disputa no campo do conhecimento e na área das agendas de pesquisa que

80 Nilma Lino Gomes, "Intelectuais negros e produção de conhecimento: algumas reflexões sobre a realidade brasileira" in Boaventura de Sousa Santos e Maria Paula Meneses (orgs.), Epistemologias do Sul (Coimbra: Almedina-CES, 2009), pp. 419-441; Gayatri Chakravorty Spivak, Pode o subalterno falar? Belo Horizonte: Editora UFMG, 2018, p. 21.

81 Kabengele Munanga, "Prefácio” in Ana Rita Santiago et. al. (orgs.), Descolonização do conhecimento no contexto Afro-brasileiro (Cruz das Almas: Editora UFRB, 2019), pp. 9-14.

82 Renato Noguera, O ensino de Filosofia e a lei 10.639, Rio de Janeiro: Biblioteca Nacional, 2014, p. 20. 
está atrelado aos processos de subalternidade, da colonialidade e do racismo em sua vertente epistêmica. Por essas razões, o combate do racismo e da injustiça cognitiva passa pelo devido reconhecimento das produções intelectuais de todos os povos. No caso dos povos africanos, que foram alvos de um longo processo de diáspora, escravização e de colonização brutal - ainda sem precedentes e de que nossa linguagem e nossas descrições parecem não conseguir dar conta, é indispensável destacar e valorizar devidamente o que tem sido historicamente depreciado. ${ }^{83}$

É perceptível o racismo epistêmico no trato das abordagens científicas produzidas por pesquisadores negros e negras, pois, historicamente, a prática acadêmica evidencia o apagamento de "biografias de intelectuais negras/os, o esvaziamento de singularidades por narrativas descontextualizadas e distanciadas da história, e isto é uma estratégia discursiva poderosa que resulta em danos irreparáveis na vida de pessoas negras” ${ }^{84}$ A população negra sempre esteve na condição de marginalidade e subalternidade na sociedadelatino-americana, enocampo da cogniçãonãoédiferente.Umadas características do racismo é colocar o outro aprisionado em imagens fixas e estereotipadas e, assim, deixar em evidência uma imagem que destaca os privilégios de um segmento racialmente hegemônico, no caso, os do universo branco. Então indagamos: quem são os sujeitos com produção científica legitimados na academia latino-americana? Esses intelectuais com direito ao discurso têm cor/raça? Têm classe social? Têm gênero? Esses são alguns questionamentos que consideramos necessários para falar de intelectualidade negra e de racismo epistêmico.

A escritora e psicóloga Grada Kilomba, traz à luz o questionamento acerca da erudição e da ciência como ligados ao poder e à autoridade racial. ${ }^{85}$ Nessa perspectiva, a autora indaga: qual conhecimento está sendo

83 Noguera, O ensino de Filosofia, p. 99.

84 Zilda Martins et al., "Do racismo epistêmico às cotas raciais: a demanda por abertura na universidade”, Revista Eco-Pós, v. 21, n. 3 (2018), pp. 124-125.

85 Grada Kilomba, Memórias da plantação: episódios de racismo cotidiano, Tradução Jess Oliveira, Rio de Janeiro: Cobogó, 2019, p. 29. 
reconhecido como legítimo? E qual conhecimento não o é? Qual conhecimento tem feito parte das agendas acadêmicas? E qual conhecimento não? De quem é esse conhecimento? Quem é reconhecido como alguém que possui conhecimento? E quem não o é? Quem pode ensinar conhecimentos? E quem não pode? Quem está no centro? E quem permanece fora, nas margens? Essas questões nos instigam a refletir sobre os lugares que o sujeito negro tem ocupado no espaço acadêmico. Espaço este que

não é um local neutro. Ele é um espaço branco onde o privilégio de fala tem sido negado para as pessoas negras. Historicamente, esse é um espaço onde temos estado sem voz e onde acadêmicas/os brancas/os têm desenvolvido discursos teóricos que formalmente nos construíram como a/o "Outras/os" inferior, colocando africanas/os em subordinação absoluta ao sujeito branco. Nesse espaço temos sido descritas/os, classificadas/os, desumanizadas/os, primitivizadas/os, brutalizadas/os, mortas/os. Esse não é um espaço neutro. ${ }^{86}$

As reflexões tecidas até aqui também são resultantes do tensionamento racial no tocante à produção de conhecimento, aos espaços que ocupamos como mulheres negras na universidade, que nos permitem constatar as ausências das epistemologias negras, e que, portanto, nos respaldam com respeito à importância de descolonizar, desembranquecer, feminizar e enegrecer os saberes, e, por conseguinte, os espaços acadêmicos, na busca incessante por literaturas negras que possam representar as problemáticas sociológicas concernentes ao segmento negro, porém, em uma perspectiva epistêmica negra e afrodiaspórica. Com a entrada de pesquisadores negras e negros nas diversas áreas do conhecimento (antropologia, sociologia, economia política, história, serviço social, psicologia, letras, linguística, educação, direito, medicina etc.), observamos um alargamento significativo dos "horizontes dos estudos

86 Kilomba, Memórias da plantação, pp. 50-51 (grifos no original). 
sobre o negro ao introduzir novos temas de pesquisa, preenchendo as lacunas deixadas pelos pesquisadores tradicionais brancos". ${ }^{87}$

Nesse sentido, com a presença negra nas universidades haveria a possibilidade de uma relação dialógica e de complementariedade epistêmica entre brancos e negros, com riqueza de partilhas e trocas de conhecimentos mutuamente. Quiçá ainda seja um horizonte utópico em virtude da existência do racismo institucional, que determina e demarca os lugares sociais nos espaços de poder, entre eles, o poder de legitimar a quem se adjudica a autoridade epistêmica. A universidade se torna o lugar explícito do racismo institucional porque a prática racista está entranhada na espinha dorsal das estruturas e instituições desde o período colonial escravista. Na denúncia do silenciamento epistêmico e das formas explícitas e veladas do racismo e do sexismo vivenciado por intelectuais negras e negros, aferimos que tal invisibilização e violência racial não são ingênuas e ocasionais. Entretanto, foi no contexto dos anos 1990 que a intelectualidade negra paulatinamente iniciou um processo de reivindicação de seu lugar de fala, ganhando visibilidade e consagração. Esse processo se realizou devido a diversos fatores, entre eles, o de compreender as desigualdades sociorraciais para além dos aspectos socioeconômicos. E a pressão por parte dos movimentos sociais, sobretudo, do movimento negro, com caráter inovador, contestador no âmbito da produção de conhecimento no campo das ciências sociais e humanas, inaugurou uma nova fase de produções de saberes articulados com suas vivências nos e com os movimentos sociais. ${ }^{88}$ Neste ínterim, esses intelectuais negras e negros se localizam no campo científico, pois

produzem um conhecimento que tem por objetivo dar visibilidade a subjetividades, desigualdades, silenciamentos e omissões em relação a determinados grupos sociorraciais e suas vivências. Para tal, configuram-se como um coletivo, organizam-se e criam associações científicas

87 Munanga, “Prefácio”, p. 13.

88 Gomes, “Intelectuais negros”, p. 421. 
a fim de mapear, problematizar, analisar e produzir conhecimento. É aqui que se localizam os intelectuais negros. ${ }^{89}$

A intelectualidade negra tem desafiado, teórica e metodologicamente, a análise sociológica, centralizando as imbricações das dimensões socioeconômicas, culturais e políticas intrínsecas à questão racial, enquanto também propõe uma abordagem não hierarquizada dessas dimensões. Nesse contexto, o papel dos intelectuais negras e negros tem sido, sobretudo, o de questionar a produção acadêmica e o lugar da “outricidade” representada pela comunidade negra no âmbito da produção de conhecimento. Em virtude de um sistema racista, nossas vozes foram sistematicamente desqualificadas, jogadas às margens, como conhecimento inválido e acientífico. ${ }^{90}$

A presença de sujeitos negros nos círculos intelectuais latino-americanos, ainda que minoritária, deve-se a uma nova geração de negras e negros que se insere nas universidades durante e após a conclusão da pós-graduação, fato fundamental para pautar um olhar crítico e analítico, ao tematizar a questão racial nas diversas áreas do conhecimento. Em suas dissertações e teses desenvolvem análises críticas acerca das desigualdades raciais e dos racismos cotidianos vivenciados por eles mesmos enquanto pessoas negras. Essa inserção universitária traz tensões, ao ameaçar territórios das ciências sociais e humanas sacralizados no universo acadêmico, que legitimou o sujeito branco como "especialista” da cultura negra e das relações étnico-raciais.

Isso significa que, a partir do momento que pesquisadores negras e negros adentram o universo acadêmico e começam a desenvolver estudos nessa área, deparam-se com conhecimentos social e politicamente localizados, porque partem de um local de enunciação, ou seja, de um lugar de fala. Logo, esse sistema racista alicerçado é abalado, o que causa fissuras nas estruturas em que os racismos operam, na análise em questão, o racismo epistêmico. São evidentes as disputas de narrativas nos espaços

89 Gomes, "Intelectuais negros”, pp. 421.

90 Gomes, “Intelectuais negros”, p. 433; Kilomba, Memórias da plantação, p. 34. 
de poder científico, resultando em produções científicas que partem de um lugar racialmente situado e não deslocado dos sujeitos que as produzem.

Deste modo, ratificamos as evidências de como o racismo estrutura todas as relações sociais, econômicas e acadêmicas. A falta de intelectuais negros e negras na universidade e nas bibliografias implica no apagamento da intelectualidade negra e das epistemologias negras na construção do conhecimento. Isso significa que o campo universitário acaba por reproduzir e manter essa política excludente e racista, com uma produção eurocêntrica e eurocentrada na supremacia branca europeia, e "reafirma o imaginário que, em geral, associa competência e mérito a condições como branquitude, masculinidade e heterossexualidade e cisnormatividade". ${ }^{91}$

Nessa perspectiva, concordamos com análises contemporâneas sobre o racismo estrutural e epistêmico, sobretudo na universidade, por considerarmos que a academia "toma para si o direito de dizer o que e quem deve ser lido, que história deve ser contada, como e por quem. Logo, a academia é um reflexo da sociedade misturada a uma ausência de autocrítica". ${ }^{22}$ Essa subalternização intelectual engendrada e perpetuada pelo universo acadêmico reflete-se na pouca representatividade negra, seja de discentes ou docentes, presente nesse espaço social epistemológico, resultando na legitimação dessas estruturas e hierarquias sociais e raciais construídas socialmente que mantêm o segmento negro "num lugar silenciado estruturalmente”, ${ }^{93}$ Isso reverbera nas produções intelectuais e saberes deste grupo racializado, bem como, no não acesso aos espaços universitários.

Por outro lado, esses pesquisadores têm criado ferramentas teórico-metodológicas de modo a enfrentar esses silêncios institucionais acarretados pela violência racista. Uma delas consiste em adentrar e ocupar lugares historicamente negados à população negra, a propósito, a universidade. Outra forma de romper com essa lógica é produzir escritos

91 Silvio Almeida, O que é racismo estrutural? Belo Horizonte: Letramento; Justificando, 2018.

92 Martins et al., "Do racismo epistêmico”, p. 132.

93 Ribeiro, O que é lugar de fala?, p. 63. 
de cunho descolonizador, trazendo a questão racial para o centro do debate, via pesquisas que elaborem sobre um temário racialmente localizado e afrocentrado.

Nessa perspectiva, apresentamos alguns fundamentos no que concerne ao rompimento das hierarquias instituídas pelo discurso autorizado, enfatizando que "existe nesse espaço uma disputa de narrativa, mas ainda aquém do ideal por conta das barreiras institucionais que impedem o acesso de vozes dissonantes”. ${ }^{94}$ Esse efeito é determinante na legitimidade e autorização de quem pode falar e produzir conhecimentos.

Qualquer forma de saber que não se enquadre na ordem eurocêntrica de conhecimento tem sido continuamente rejeitada, sob o argumento de não constituir ciência credível. A ciência não é, nesse sentido, um simples estudo apolítico da verdade, mas a reprodução de relações raciais de poder que ditam o que deve ser considerado verdadeiro e em quem acreditar. ${ }^{95}$

No entanto, nessa trincheira epistemológica, o sujeito branco tem assegurado seu lugar de poder e de privilégios em detrimento de um grupo racializado, em que os discursos de intelectuais negras e negros são considerados menos válidos, meramente ideológicos e desprovidos de credibilidade. Nessa acepção, importa sublinhar que esse "racismo constitui todo um complexo imaginário social que a todo momento é reforçado pelos meios de comunicação, pela indústria e pelo sistema educacional”. ${ }^{96}$ Então indagamos: Quem tem permissão de produzir conhecimentos e narrativas? Contudo, destacamos que há uma disputa de narrativas, que tem se tornado uma verdadeira batalha no campo dos

94 Ribeiro, O que é lugar de fala? p. 87.

95 Kilomba, Memórias da plantação, pp. 53-54.

96 Almeida, O que é racismo estrutural? p. 51. 
saberes no que tange à erudição e à ciência ligados à autoridade racial, em que historicamente o sujeito negro foi emudecido. ${ }^{97}$

Ao evidenciarmos a realidade experienciada pela intelectualidade negra, expusemos o olhar colonizador que recai sobre nossos corpos, saberes e produções científicas. Além disso, refutamos esse olhar, ressaltando a necessidade de analisarmos as relações étnico-raciais a partir de lentes analíticas não eurocêntricas. Tal necessidade resulta da constatação de que o racismo científico perdura e influencia o imaginário social, ademais invisibiliza e marginaliza a produção científica de pesquisadores negros e negras na América Latina.

Sob esse horizonte, para além do sistema de cotas raciais temos de avançar no escurecimento da universidade numa perspectiva negra, de representatividade negra, de epistemologias negras e afrodiaspóricas desde a bibliografia até a inserção dos intelectuais negros e negras nesses espaços de produção dos saberes, de construto científico. Enfatizamos que nossa escrevivência parte de um lugar de enunciação e de atravessamentos, que ancora-se em deslocamentos costurados com fios de experiências múltiplas, enredadas por histórias e potencialidades de mulheres e homens negros. ${ }^{98}$ Portanto, nossa escrevivência possibilita romper epistemologicamente com histórias obliteradas pelo colonialismo científico.

Quando produzimos conhecimentos, nossos discursos e escritos incorporam não apenas palavras de teor acadêmico, mas também palavras de luta, de dor, a dor causada pela histórica opressão racista, sexista, entre outras. Nossos saberes carregam histórias marcadas por ausências, silêncios e invisibilidades cunhadas desde o período escravocrata. A escravidão deixou marcas profundas no corpo e no pensamento que ainda vivenciamos mesmo após a abolição. Enegrecer a produção do conhecimento, a priori, é

97 Kilomba, Memórias da plantação, p. 34.

98 A palavra “escrevivência” foi cunhada pela escritora Conceição Evaristo. Não era sua intenção criar um conceito, mas apontar a necessidade de que nossos escritos, como mulheres negras, tivessem uma intencionalidade epistemológica, qual seja, a de incomodar e provocar fissuras no interior da produção científica, ao mesmo tempo não adormecer os da casa-grande nos seus sonos injustos. 
também criar uma nova linguagem, fazer ressurgir a outra narrativa, negada historicamente, e que provoca fissuras e tensionamentos para desestabilizar a norma imposta pelo regime discursivo dominante. A importância de falar e expressar uma análise embasada em outro viés epistemológico, de um lugar tido como periférico, nos permite transgredir a linguagem do academicismo clássico, sobretudo, destoar vozes, a partir de outras vozes dissonantes e insurgentes no universo epistêmico, de modo a descolonizar, enegrecer, desembranquecer e feminizar o conhecimento acadêmico. ${ }^{99}$

Essa postura epistemológica negra busca superar as políticas coloniais impostas aos corpos e produções do povo negro, visando construir estratégias de descolonização dos discursos criados socialmente como marginais e deslocados da cientificidade. Nessa tentativa intencional de deslegitimar a produção de intelectuais negros e negras, demarcamos a existência de diferentes perspectivas alternativas à lógica eurocêntrica hegemonicamente dominante e cimentada no universo acadêmico e científico, possibilitando pensar outros saberes advindos e tecidos por pesquisadores e pesquisadoras, escritores e escritoras, e intelectuais negros e negras. Ao pensarmos nesses processos de ruptura com a epistemologia eurocentrada, causamos rasuras no fazer científico ocidentalizado e problematizamos as bibliografias canônicas autorizadas no âmbito da produção sociológica, ao tempo que visamos desenterrar as bases epistêmicas soterradas. Isso em favor da visibilidade e reconhecimento do exercício e fazer intelectual negro nesse espaço permeado de micropoderes e racismos. Isso nos leva a aferir que:

Essa incipiência de recepção às intelectuais negras [e negros] e o pouco respeito ao seu trabalho também não são inocentes. Reafirmar o falso pressuposto de que são quase sem possibilidades de desenvolvimento de competências para o trabalho intelectual. Advém, inclusive, da

99 Vilma Piedade, Dororidade, São Paulo: Editora Nós, 2017, p. 35; Kilomba, Memórias da plantação, p. 213. 
suspeita da excelência de sua intelectualidade e da negação desse papel por ela [ele] exercido. ${ }^{100}$

Ana R. Santiago nos leva a refletir sobre a existência da solidão no fazer científico, do isolamento e, até mesmo, a desistência de permanecer neste ofício acadêmico. Nesse embate, há de se considerar, por fim, que a intelectualidade negra vem construindo insurgências e contraolhares em suas produções intelectuais, fazendo ecoar saberes e fazeres interditados e negados há séculos pelo racismo no espaço acadêmico. A questão aqui suscitada não é só retórica, "pois coloca no centro a questão da produção do conhecimento, a legitimidade e a política acadêmica”. ${ }^{101}$ Então questionamos: Quem são os intelectuais que temos como referência no universo escolar e universitário? E qual a presença das epistemologias negras e afrodiaspóricas no âmbito da produção científica concernente à sociologia latino-americana?

\section{Considerações finais}

Ao problematizarmos o caráter marginal das epistemologias negras e afrodiaspóricas na produção científica do campo sociológico, tratamos de enfatizar que essas questões emergem devido à ausência do segmento negro não apenas nos espaços de poder e no mercado de trabalho, mas, sobretudo, no universo acadêmico científico. Vimos que no panorama social e histórico houve e, ainda perdura, um silenciamento e negação de saberes advindos de outras epistemes que não sejam aquelas reconhecidas no âmbito do paradigma ocidental moderno. No que tange à produção do conhecimento nas universidades, o racismo científico continua a demarcar

100 Ana Rita Santiago, "Intelectuais negras: entre a invisibilidade e a resistência” in Ana Rita Santiago et. al., Descolonização do conhecimento no contexto afro-brasileiro (Cruz das Almas: Editora UFRB, 2019), pp. 51-62, pp. 55-56.

101 Figueiredo e Grosfoguel, “Racismo à brasileira”, p. 98. 
quais são as epistemologias válidas e a quem está conferido o lugar legítimo de autoridade epistêmica, deixando à margem ou à condição de “objetos de pesquisa” o povo negro, os povos originários, a comunidade cigana, camponeses e povos tradicionais.

Nesse sentido, o racismo científico ainda persiste na América Latina, de forma desvelada, sistêmica e institucionalizada, pela ausência da intelectualidade negra no centro dos debates dos principais eventos acadêmicos da sociologia latino-americana, expressão de um racismo que se manifesta na desvalorização, desautorização e secundarização das suas contribuições acadêmicas. Também se revela na ausência, invisibilidade e incipiência, na literatura da área, de categorias analíticas produzidas por intelectuais negras e negros no âmbito das disciplinas dos cursos de ciências sociais das universidades latino-americanas. Esse racismo contribui, sobremaneira, na tentativa de silenciamento e invisibilização das epistemologias negras e afrodiaspóricas, e para a impossibilidade de se fazer difundir, espraiar e enegrecer os saberes do sujeito negro.

Essa encruzilhada epistemológica é necessária para descolonizar e afrocentrar a produção acadêmica. ${ }^{102}$ Conforme Gonzalez, o racismo estabeleceu uma hierarquia racial e cultural, a partir da superioridade branca, que legitimou a crença em torno da inferioridade negra-africana, da inexistência de história e razão em suas epistemologias e ontologias, despojando-nos “do nosso legado histórico, da nossa dignidade, da nossa história e da nossa contribuição para o avanço da humanidade nos níveis filosófico, científico, artístico e religioso”. ${ }^{103}$ Portanto, a intelectualidade negra tem sofrido diversas formas de racismos, no caso em questão, o racismo epistêmico ou científico, vide o epistemicídio, ou seja, o extermínio do pensamento do outro, no formato colonial, sequestrando e silenciando saberes e práticas. Também na hierarquização dos saberes,

102 Molefi K. Asante, Afrocentricity, Trenton: Africa World Press, 1988.

103 Lélia Gonzalez, “A categoria político-cultural de amefricanidade”, p. 77. 
na delimitação da localização social, territorial, e sobretudo, racial no fazer científico e acadêmico reconhecidos como conhecimento válido. ${ }^{104}$

Contudo, é sabido que a sociologia, enquanto ciência, se estrutura como uma forma de interpretar a realidade social, adquirindo envergadura histórica e abrindo caminhos a serem trilhados rumo a horizontes diversos, criando possibilidades para desafiar o pensamento hegemônico. Ao reivindicarmos a inserção das epistemologias negras e da diáspora ao método e à teoria sociológicos, buscamos dar visibilidade às perspectivas analíticas oriundas de experiências e escrevivências a partir de outros lugares de fala, não reforçando o mito da democracia racial, mas sim permitindo espaço de produção e visibilidade científica ao povo negro.

A ausência da população negra nesses espaços impacta significativamente na estima e na imagem social destas, sem falar no direito que temos de estar e permanecer em quaisquer espaços em que queiramos estar. Urge a necessidade de feminizar e descolonizar, começando pelo meio acadêmico, pela ciência, onde o racismo se perpetuou, ou seja, enegrecer os saberes, romper com práticas de fazer ciência por meio da negação, da invisibilização e inferiorização de outras epistemologias, tornar preto nossa inter-pretação, subvertendo a ordem acadêmica e desembranquecendo a lógica eurocêntrica, para então, construir contraolhares e narrativas afrocentradas.

Elaborar uma reinterpretação da produção sociológica latino-americana, em termos de identificar as assimilações de uma perspectiva eurocentrada e de analisar as ausências e as rejeições dessa ciência no reconhecimento das epistemologias negras e afrodiaspóricas, é parte de um continuum reflexivo para pensar o projeto moderno-colonial em permanente estruturação. Trata-se também de uma reinterpretação atravessada por um lugar mais ativo e crítico de uma resistência epistemológica negra atrelada a uma vindicação de uma justiça epistêmica

104 Gabriel Nascimento, Racismo linguístico: os subterrâneos da linguagem e do racismo, Belo Horizonte: Letramento, 2019, p. 15. 
no reconhecimento de outras formas epistemológicas de interpretar a realidade social de nossa região, não em uma perspectiva marginal, mas em pé de igualdade pelo que tem a dizer em uma teoria e um método também legítimos.

Recebido em 24 dez. 2019

Aprovado em 26 set. 2020

doi: 10.9771/aa.v0i62.34966 
Este artigo analisa o não lugar da questão racial e das epistemologias afrodiaspóricas no pensamento social e na sociologia latino-americana. Argumentamos que ainda é incipiente uma produção do conhecimento no campo sociológico que atente para o caráter marginal conferido às epistemologias africanas e afrodiaspóricas, resultado do racismo científico e da invisibilização dessas epistemologias. Problematizamos este debate enfatizando a necessidade histórica de uma produção sociológica que leve em consideração as epistemologias diaspóricas no processo de teorização sociológica e de seu papel na interpelação do suposto caráter universal de uma ciência eurocentrada e branca em detrimento de outros referentes epistêmicos do fazer sociológico.

Questão racial | Epistemologias afrodiaspóricas | Sociologia latino-americana | Racismo epistêmico | Descolonização científica

\section{MARGINALIZED EPISTEMOLOGIES:}

\section{The Racial Question in Latin American Sociological Debate}

This article analyzes the absence of the racial question and African diasporic epistemologies in Latin American sociology and social thought. We argue that the production of knowledge that addresses the marginalization of African and African diasporic epistemologies in Latin American sociology is still incipient, as the result of scientific racism and the lack of visibility of these epistemologies. We further this debate by emphasizing the historical need for a sociological production that takes into account diasporic epistemologies in the process of sociological theorizing, and their role in questioning the supposedly universal character of an Eurocentric and white science, to the detriment of other epistemic referents of sociology.

Racial question | Afro-diasporic epistemologies | Latin American sociology | Epistemic racism | Scientific decolonization 